\title{
DS Mayfield
}

\section{Variants of hypólepsis: Rhetorical, Anthropistic, Dramatic (With Remarks on Terence, Machiavelli, Shakespeare)}

\section{The Dynamics of Cultural Networks: Floating dicta}

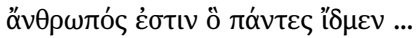 \\ Democritus $^{1}$
}

Everyone knows Protagoras' notorious assertion that 'man is the measure of all things' - an answer to the (implicit) question 'what is a human being'. Democritus is taken to have said that 'man is a microcosm', that 'man is what

1 Die Fragmente der Vorsokratiker, edited by Walther Kranz, translated by Hermann Diels, 3 vols. Zurich: Weidmann, 1985, vol. 2, pp. 177 f., 68B165). On 'floatation' in the '(virtual) cultural network', see Küpper (The Cultural Net. Early Modern Drama as a Paradigm. Berlin: de Gruyter, 2018; "Rhetoric and the Cultural Net: Transnational Agencies of Culture". Rhetoric and Drama, edited by DS Mayfield. Berlin: de Gruyter, 2017, pp. 151-175; Mayfield. "Proceedings”. Rhetoric and Drama, pp. 203-229, pp. 220-222; "Interplay with Variation: Approaching Rhetoric and Drama”. Rhetoric and Drama, pp. 3-52, spec. pp. 3-5, 9-10, 36-38).

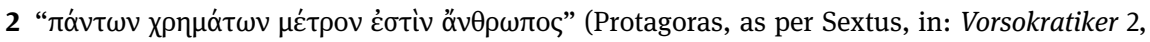
p. 263, 80B1; see Sextus Empiricus. Against the Logicians, edited and translated by R. G. Bury. Cambridge: Harvard UP, 1983, pp. 30-33, I.60-61); see also 'pánton chremáton métron ánthropon einai' (Protagoras, as per Plato, in: Vorsokratiker 2, p. 263, 80B1); "Protagoras [...] says somewhere that man is 'the measure of all things[']" (Plato. "Theaetetus". Theaetetus. Sophist, edited and translated by H. N. Fowler. Cambridge: Harvard UP, 2006, pp. 1-257, p. 41, 152A). Drawing on Aristotle, Cicero emphasizes (as does Quintilian): "scriptasque fuisse et paratas a Protagora rerum inlustrium disputationes, quae nunc communes appellantur loci" (Vorsokratiker 2, p. 266, 80B6); "Protagoras wrote out and furnished discussions of certain large general subjects such as we now call commonplaces" (Cicero. "Brutus.” Brutus. Orator, edited and translated by H. M. Hubbell. Cambridge: Harvard UP, 1962, pp. 18-293, p. 49, xi.46).

Note: The paper from which this essai evolved was presented at Freie Universität Berlin on April 30, during the 2015 DramaNet conference; the author wishes to thank its organizers, as well as the editors of the present volume, especially Dr. Sven Thorsten Kilian. The article at hand benefitted from effectual comments on the part of Prof. Kathy Eden (Columbia University) and Prof. Joachim Küpper (Freie Universität Berlin). 
everyone knows'. ${ }^{3}$ Virtually all of Aristotle's works open with a statement concerning the 'tò tí en einai' of human beings: de anima distinguishes man as 'the calculating animal'. ${ }^{4}$ The Politics offers 'man as a political animal' - more precisely: 'it is political more than any other gregarious animal, since it is capable of speech and reason'. ${ }^{5}$ The Poetics asserts: 'man is the most mimetic of all animals'. ${ }^{6}$ The first sentence of the Metaphysics reads: "All men naturally de-

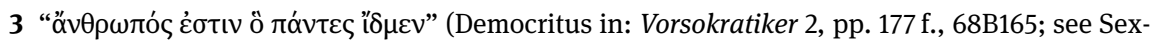
tus. Outlines of Pyrrhonism, edited and translated by R. G. Bury. Cambridge: Harvard UP, p. 166, II.23); 'man, a microcosm,' 'mikrón kósmon,' 'toi anthrópoi mikroi kósmoi' (Vorsokratiker 2, p. 153, 68B34); see Hans Blumenberg's reference to Democritus' "Daß der Mensch eine kleine Welt sei” (Theorie der Unbegrifflichkeit, edited by Anselm Haverkamp. Frankfurt: Suhrkamp, p. 69).

4 "Imagination in the form of sense is found [...] in all animals, but deliberative imagination only in the calculative [animals: zóois logistikois]" ("On the Soul," On the Soul. Parva Naturalia. On Breath. Translated by W. S. Hett. Cambridge: Harvard UP, 2000, pp. 1-203, here p. 192 f.,

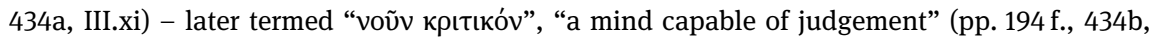
III.xii). For the phrase 'tò tí en einai', see p. 70, 412b, II.i; Blumenberg considers it to be "untranslatable” (Begriffe in Geschichten. Frankfurt: Suhrkamp, 1998, p. 242; trans. dsm).

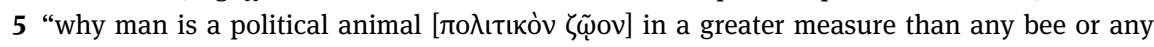
gregarious animal is clear [...] man alone of the animals possesses speech [ $\lambda$ óyov]" (Politics, edited and translated by H. Rackham. Cambridge: Harvard UP, 1944, pp. 8-11, 1253a, I.i.9-10); "for it is the special property of man in distinction from other animals that he alone has perception of good and bad and right and wrong” (pp. 9 f., 1253a, I.i.11). On the Stoic conception see e.g. Marcus Aurelius (Meditations, edited and translated by C. R. Haines. Cambridge: Harvard UP, 1930, p. 56, III.7; p. 58, III.9); the former is based on Aristotle, as per Sextus: "Others used to assert that "Man is a rational mortal animal, receptive of intelligence and science"” (Outlines, p. 169, II.26; see 168n.). The latter aims to take such definitions apart (see pp. $286 \mathrm{f}$., II.211). Compare Blumenberg: "Das Merkmal der Vernünftigkeit steht in einer auflösbaren und der Funktion nach zweifelhaften Verbindung mit dem Leib als seinem Instrument. Mit anderen Worten: die klassische Definition des Menschen als des vernünftigen Lebewesens verpflichtet die Theorie nicht dazu, die Vernünftigkeit als eine gerade für dieses Lebewesen notwendige und integrale Leistung aus seinen Existenzbedingungen heraus zu verstehen. Dies wäre nur möglich, wenn Vernunft als das Minimum der Leistungsvoraussetzungen der Selbsterhaltung für dieses organische System, diesen Leib vom Eidos Mensch, erwiesen werden könnte. Die klassische Definition ist also nicht nur anthropologisch bedeutungslos, sondern geradezu Anthropologie verhindernd" (Beschreibung des Menschen, edited by Manfred Sommer. Frankfurt: Suhrkamp, 2006, p. 510).

6 "For it is an instinct of human beings, from childhood, to engage in mimesis (indeed, this distinguishes them from other animals: man is the most mimetic of all[)]" ("Poetics," edited and translated by Stephen Halliwell. Aristotle. Poetics. Longinus. On the Sublime. Demetrius. On Style, edited by W. H. Fyfe et al. Cambridge: Harvard UP, 1995, pp. 27-141, p. 37, 1448b, § 4) a matter of gradation, not an absolute difference; man is indeed an animal (still); similarly, in the above definition (see Politics, pp. 8-11, 1253a, I.i.9-10). 
sire knowledge” (Metaphysics 1-9, pp. 2f., 980a, I.i.1). ${ }^{7}$ From suchlike statements, the Pyrrhonist Skeptic Sextus Empiricus inferred that "man is not only unknowable, but even unthinkable'. ${ }^{8}$ In the twentieth century, Adorno asserted: 'One cannot state what man is, and this puts a veto on all anthropology'.' Even so, the query 'what is a human being' persists. One reason may be Kant's assessing his catalog of questions - 'what can I know', 'what shall I do', 'what may I hope', 'what is man' - as coming down to the last item. ${ }^{10}$ One might

7 'Pántes ánthropoi tou eidénai orégontai phýsei' (Metaphysics. Books 1-9, edited and translated by Hugh Tredennick. Cambridge: Harvard UP, 1933, pp. 2 f., 980a, I.i.1). For Sextus' comment on the Aristotelian opening sentence, see Blumenberg (Die Legitimität der Neuzeit. Frankfurt: Suhrkamp, 1999, p. 314; see Sextus, Outlines, pp. 2-3, I.1); also as to Augustine, altering Aristotle's line (Blumenberg, Legitimität, p. 365); concerning the Medieval, Scholastic reception of Aristotle's introductory sentence (pp. 383, 405): "Bei Thomas von Aquino [...] ist der erste Satz der aristotelischen 'Metaphysik' zu einem der schlechthin gültigen und in vielfacher Argumentation genutzten Prinzipien des scholastischen Denkens erhoben. Die Natürlichkeit des Wissensstrebens impliziert die Wertung: omnis scientia bona est" (pp. 384; see 384n.385n.).

8 See Sextus: "Now 'Man' [...] seems to me, so far as regards the statements made by the Dogmatists, to be not only non-apprehensible but also inconceivable. [...] when they wish to establish the concept of 'Man' they disagree in the first place, and in the second place they speak unintelligibly. Thus Democritus declares that 'Man is that which we all know'. Then, so far as his opinion goes, we shall not know Man, since we also know a dog, and consequently Dog too will be man. And some men we do not know, therefore they will not be men. Or rather, if we are to judge by this concept, no one will be a man; for since Democritus says that Man must be known by all, and all men know no one man, no one, according to him, will be a man" (Outlines, pp. 165-167, II.22-24). There appears to be a structural relation of Anselm of Canterbury's ontological proof of God to the initial sentence above; see Blumenberg: "der mittelalterliche Erfinder des Arguments unterscheidet selbst zwischen dem Gott seines Beweises, über den hinaus nichts Größeres gedacht werden kann, und dem Gott seines Offenbarungsglaubens, der größer sei als alles, was überhaupt gedacht werden könne” (Legitimität, p. 111); "Ergo Domine, non solum es quo maius cogitari nequit sed es quiddam maius quam cogitari possit" (Anselm, "Proslogion," chapter XV, cited by Blumenberg, Legitimität, p. 564); see what the latter calls "die Forcierung der negativen Sprache" (p. 565).

9 "Was der Mensch sei, läßt sich nicht angeben. [...] Daß nicht sich sagen läßt, was der Mensch sei, ist keine besonders erhabene Anthropologie sondern ein Veto gegen jegliche" (cited by Blumenberg, Beschreibung, pp. 487 f.); see "Die Erneuerung der philosophischen Anthropologie in den [1920ern] [...] begann nicht zufällig mit dem traditionell nur als Paradox möglichen Satz von Max Scheler: ... die Undefinierbarkeit gehört zum Wesen des Menschen” (p. 510).

10 "Kants berühmte[r] Katalog philosophischer Fragestellungen [...]: 1. Was kann ich wissen? 2. Was soll ich tun? 3. Was darf ich hoffen? 4. Was ist der Mensch? [...] Im Grunde könnte man aber alles dieses zur Anthropologie rechnen, weil sich die drei ersten Fragen auf die letzte beziehen" (Blumenberg, Beschreibung, pp. 500 f.; see Immanuel Kant. Schriften zur Metaphysik und Logik 2. Werkausgabe, 12 vols., edited by Wilhelm Weischedel, vol. 6. Frankfurt: Suhrkamp, 1977, p. 448, Einleitung III). These queries delineate philosophy "in sensu cosmico", the "field of philosophy in this cosmopolitan ['weltbürgerlichen'] sense” (p. 447; trans. dsm): 
almost be tempted to submit that 'man is the animal that cannot stop asking and answering the question what man is'. ${ }^{11}$

This essai is structured as follows: a methodical second section ensues after the present exposition; the third part addresses the term 'hypólepsis' from a rhetorical, anthropistic, and dramatic perspective; a fourth section tenders variations on the Terentian 'nihil humani'; the conclusion is concerned with the most elemental level of the above query.

"1) What can I know? - / 2) What shall I do? / 3) What may I hope? / 4) What is man?" (p. 448; trans. dsm). Metaphysics answers the first, ethics the second, religion the third, anthropology the last query, as per Kant (see p. 448) - who tentatively subsumes the first three questions (hence their answers) under the last one: 'anthropology' as the subtending systematics. See Odo Marquard: "Es gibt kaum eine Philosophie, die nicht vom Menschen handelt" (Glück im Unglück. Philosophische Überlegungen. Munich: Fink, 2008, p. 142). As per Blumenberg, the question is distinguished by its indisputability, precision, 'lapidary' nature: "Keine der philosophischen Disziplinen hat eine so unbestrittene und eindeutige Fragestellung wie diese, nämlich die lapidare Frage: was ist der Mensch?” (Beschreibung, p. 499). Arguably, the query 'what is man' (and its various answers, hence anthropistics) is the (often tacit) foundation of any discourse, affecting the notional edifice on (virtually) all strata upward. Conspicuously, Blumenberg frequently begins chapters or segments with variants answering the formula 'what is man'; in his Höhlenausgänge (Frankfurt: Suhrkamp, 1996), see e.g. the first sentence of chapter III ("So wurde der Mensch, beim Durchgang durch die Höhle, das träumende Tier", p. 29) and chapter V ("Der Mensch ist das sichtbare Wesen in einem emphatischen Sinne”, p. 55); likewise: "Der Mensch ist das Tier, das sich andere Tiere hält” (Löwen. Berlin: Suhrkamp, 2010, p. 89), opening a brief essay therein. Blumenberg employs variants of this template as a structuring device.

11 See Nietzsche's suggestive formulation: "Er ist das noch nicht festgestellte Thier" man is the 'as yet undetermined animal' (Kritische Studienausgabe [KSA], edited by Giorgio Colli and Mazzino Montinari, 15 vols. Munich et al.: dtv and de Gruyter, 1999; here: vol. 11, p. 125; trans. dsm); see Karlheinz Stierle (“Was heißt Moralistik?” Moralistik. Explorationen und Perspektiven, edited by Rudolf Behrens and Maria Moog-Grünewald. Munich: Fink, 2010, pp. 122, here p. 20); Michel Foucault (Einführung in Kants Anthropologie. Translated by Ute Frietsch, Berlin: Suhrkamp, 2010, p. 118); Arnold Gehlen's reading: “Das ist ein guter Doppelsinn, denn der Mensch ist einmal irgendwie 'unfertig', nicht festgerückt, sich selbst noch Zweck und Ziel der Bearbeitung, und dann gibt es noch keine Feststellung dessen, was eigentlich der Mensch ist" (Philosophische Anthropologie und Handlungslehre. Gesamtausgabe, edited by Karl-Siegbert Rehberg, vol. 4. Frankfurt: Klostermann, 1983, p. 75; see pp. 86, 130); he adds: "das ist ein drohendes Wort" (p. 162). Generally thereto, see Mayfield (Artful Immorality - Variants of Cynicism. Machiavelli, Gracián, Diderot, Nietzsche. Berlin: de Gruyter, 2015, pp. 198, 391-402, spec. p. 395, 395n., 413n., 430n.). 


\section{The Method of Choice: Descriptivity}

Was zu beschreiben ist, stellt sich heraus, wenn man zu beschreiben begonnen hat. Blumenberg $^{12}$

'What is a human being' - there have been and there will (in all probability) be an unlimited number of apparently finite answers to that boundless query. ${ }^{13}$ No answer has superseded all others; arguably, none shall. Apart from a (Neo-)Nominalist 'nescio', the expedient approach to such plurality and diversity - one question, myriad and manifold answers - is descriptiveness, as practiced in Blumenberg's Beschreibung des Menschen. This method tends to be discursive, limitless; its objectives provisional, the path as such the primary concern. ${ }^{14}$ Hence Blumenberg suggests the term 'Definitionsessay' ('attempts at definition') - stressing the latter's tentative, heuristic character. ${ }^{15}$

12 (Zu den Sachen und zurück, edited by Manfred Sommer. Frankfurt: Suhrkamp, 2007, p. 173). 13 Blumenberg (as to Kant): "Freilich so, in der Art einer Metafrage, kann man erst ganz spät fragen, nachdem schon lange genug gefragt worden ist: was ist der Mensch? Aber was hatte man damit wissen wollen? Welche Antwort hätte genügt?” (Beschreibung, p. 502); the latter, being a suggestive question, may allude to the philosopher's earlier emphases as to inquisitive “curiositas" - of 'man as the being plus ultra' (see Legitimität, pp. 296, 296n.-297n., 314, 324; part three passim: pp. 261-528). The implied limitlessness (see Husserl's programmatically 'infinite labor', as referenced e.g. in Beschreibung, p. 441, and section 5 herein) leads to the question of method: in Blumenberg, Beschreibung (discursive descriptiveness), instead of yet another «-logy` (including, arguably, not another 'phenomenology'; see Höhlenausgänge, p. 15); and to a tentative, provisional objective: "die Ersetzung dieser Fragestellung ['was der Mensch sei'] durch eine andere, sie modifizierende [...] Fragestellung: wie der Mensch möglich sei. [...] Die Modifikation der Fragestellung kann zunächst und zumindest an die Kontingenz des Menschen heranführen: er muß nicht sein und er muß nicht so sein, wie er ist" (Beschreibung, p. 511).

14 As to the import of 'approximation' in Blumenberg, see these instances as indicative of his method: "Tendenzen bei Annäherung an" (Die Lesbarkeit der Welt. Frankfurt: Suhrkamp, 1986, p. 162); "Annäherung an” (Lebenszeit und Weltzeit. Frankfurt: Suhrkamp, 1986, p. 249); "provisorischen Annäherungen, [...] Leitfäden” (Hans Robert Jauß et al. "Sechste Sitzung: Gemeinsame Interpretation von Apollinaires Arbre [aus Calligrammes]”. Immanente Ästhetik - Ästhetische Reflexion. Lyrik als Paradigma der Moderne, edited by Wolfgang Iser. Munich: Fink, 1966 [Poetik und Hermeneutik, 2], pp. 464-484, p. 483); see also the title of Blumenberg's respective article, and passim therein ("Anthropologische Annäherung an die Aktualität der Rhetorik [1971]". Ästhetische und metaphorologische Schriften, edited by Anselm Haverkamp. Frankfurt: Suhrkamp, 2001, pp. 406-431; "Approccio antropologico all'attualità della retorica”. Il Verri. Rivista di Letteratura 35/36 [1971], pp. 49-72; "An Anthropological Approach to the Contemporary Significance of Rhetoric”. After Philosophy. End or Transformation? [1987], edited by Kenneth Baynes et al. Cambridge: MIT P, 1993, pp. 429-458). Generally, see Heraclitus:

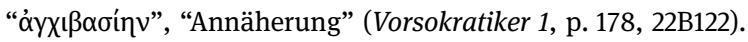


To be speaking of 'human invariants' from a 'phenomenistic' perspective in the field of 'anthropistics' has the advantage of avoiding the implications of a deductive approach. ${ }^{16}$ In this, the essai at hand follows Blumenberg, decidedly entitling his corresponding monograph Description of Man. ${ }^{17}$ One reason he gives is this: "Every anthropology, including such as deny this [fact], is historical at core" (Beschreibung, p. 890; trans. dsm); in one sense, this signifies that opinions about man's 'tò tí en einai' are variable. ${ }^{18}$ His answer as to the utility of '(human) invariants' is twofold: "no science [or 'scholarship'] is at all able to operate rationally without introducing and establishing constants" (Beschreibung, p. 485; trans. dsm); and there can "be no theory of variants that

15 "Insofern sie Annäherungsversuche an die Definition sein könnten, will ich sie als 'Definitionsessays' bezeichnen. Was sie charakterisiert, ist die Verbindung zwischen dem formalen Anspruch auf Allgemeinheit und der materialen Resignation auf den partiellen Aspekt" (Beschreibung, p. 511) - perchance a form of Neo-Nominalism; some instances: "Man is a being of poor intelligence, which is dominated by its wishes" (Freud as quoted by Marcuse, cited in: Blumenberg Beschreibung, p. 513; trans. dsm); "Mankind is a species of monkey suffering from megalomania" (Vaihinger in: Beschreibung, p. 514; trans. dsm); "I believe that man is ultimately so free a being that it is impossible to deny it the right to be what it believes to be" (Lichtenberg in: Beschreibung, p. 516; trans. dsm); see also: "one is tempted to define man" (Oscar Wilde. "The Critic as Artist". The Artist as Critic, edited by Richard Ellmann. New York: Random House, 1982, pp. 340-408, here p. 388). 'Definitionsessay' is 'paradoxical' (a contradiction in conventional terms), since 'definition' implies or claims finality (as do deductive approaches, typically ending in <-logy ), which is literally at variance with the tendency of an 'essai'; for a factual implementation of the latter qua poetic program, see Montaigne qua 'source type'; for the latter term (mutatis mutandis), see Jurij M. Lotman (Die Struktur literarischer Texte. Translated by Rolf-Dietrich Keil, Munich: Fink: 1972, p. 151, 151n.). In general, see Holenstein (in another context): "In der Wissenschaftstheorie wird der teleologischen Fragestellung seit Kant ein heuristischer Wert zugestanden" ("Einführung: Von der Poesie und der Plurifunktionalität der Sprache”. Poetik. Ausgewählte Aufsätze 1921-1971, edited by Elmar Holenstein and Tarcisius Schelbert. Frankfurt: Suhrkamp, 1979, pp. 7-57, p. 8) - emphasizing 'heuristic', rather than 'telic logic'.

16 So as not to turn this descriptive approach into yet another «-logy (such as epistemology, anthropology, biology - let alone other notoriously ostensive logics). The expedient method in the field at hand is to proceed by induction, spec. qua (ac)cumulative analytics, detailed description; rather than by deduction, or analogous systematics - to say nothing of determining the supposed télos a priori and arriving at the apparently inevitable quod erat demonstrandum.

17 See Sommer’s "Editorische Notiz”: “'>Beschreibung des Menschen` ersetzt den Titel 〉Phänomenologische Anthropologier' hat sich Hans Blumenberg (1920-1996) auf einem Blatt notiert" (in: Beschreibung, p. 897).

18 This implies that a plurality and variety of conceivably familiar (common, conventional, customary) anthropistic assumptions (as to 'what a human being is') are potentially in use (circulation, currency) during a certain period, and at different times; while diverse and variable on the whole, they may seem invariable or distinctive to a given time or discourse; from a diachronic perspective, multiple and manifold answers to the query 'what is man' have a tendency to coexist. 
would not [simultaneously] advance the theory of constants" (Beschreibung, p. 487; trans. dsm). Blumenberg also employs the term "invariance" (Beschreibung, p. 484; trans. dsm), implying variation as the apparent state of affairs. ${ }^{19}$ Assumptions concerning specific invariants will in fact vary over time: they are a matter of the communis opinio - hence changeable, (diachronically) sundry.

\section{Variants of 'Taking Up and Tying in With'}

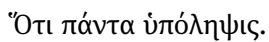

Marcus Aurelius ${ }^{20}$

The theoretical concept herein suggested as expedient for describing also the aforesaid dynamics is 'hypólepsis'. ${ }^{21}$ Its (initial) meanings are disputed, and no

19 Herein, this choice of terms ('variation', 'invariance') also follows Jakobson's approach, as applied in another field; see Holenstein's note: “Das Verhältnis Invarianz - Variation, eines der Leitprinzipien der Jakobsonschen Linguistik, das die Sprache in verschiedener Hinsicht prägt [...]. Jede Variation ist auf dem Hintergrund der sie begrenzenden Invarianten zu sehen" (in: Jakobson, Poetik, p. 83; compare also Holenstein's "Einführung," p. 21, therein; as well as his study, Roman Jakobsons phänomenologischer Strukturalismus. Frankfurt: Suhrkamp, 1975, pp. 101 ff.); see the linguist's specific formulation (the context being Poe, and Valéry's reading of the latter): "The invariance of the group is particularly stressed by the variation in its order" (Jakobson, Language in Literature, edited by Krystyna Pomorska and Stephen Rudy. Cambridge: Harvard UP, 1987, p. 87). See Blumenberg: "Aufschlußhaltigkeit [...] ergibt sich [...], wenn das Ineinandergreifen der formal entgegengesetzten Tendenzen von Konstanz und Variation [...] wahrgenommen wird" ("Wirklichkeitsbegriff und Wirkungspotential des Mythos [1971]". Ästhetische und metaphorologische Schriften, edited by Anselm Haverkamp. Frankfurt: Suhrkamp, 2001, pp. 327-405, here p. 348; initially in: Terror und Spiel. Probleme der Mythenrezeption, edited by Manfred Fuhrmann. [Poetik und Hermeneutik, 4]. München: Fink, 1983, pp. 11-66; here p. 26). See Marquard's employment of this notion (de re) in an ethical context (sensu lato): "Darum müssen wir herkömmlich leben: wir müssen stets überwiegend das bleiben, was wir schon waren; unsere Veränderungen werden getragen durch unsere Nichtveränderungen” (Philosophie des Stattdessen. Stuttgart: Reclam, 2009, p. 71).

20 (Meditations, p. 326, XII.8; p. 330, XII.22; see p. 38, II.15; p. 70, IV.3).

21 For the Stoic term "Katalepsis" qua "grasp" (including the Zenonic anecdote on the concept’s coinage), see Blumenberg (Legitimität, pp. 298 f.; trans. dsm; compare p. 312). Among the books by the (unorthodox) Stoic Herillus of Carthage, D. Laertius notes one with the title

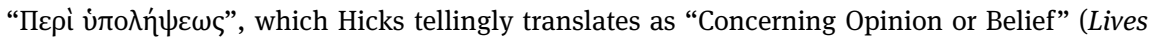
II, pp. 270-271, VII.166; see p. 273, VII.167; and von Arnim, Stoicorum Veterum Fragmenta [SVT].

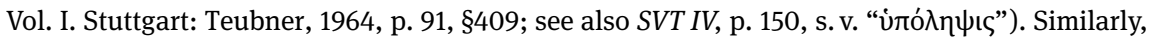
two of Chrysippus' works on Logic contain the term: first, "Of the Arguments affecting Ordinary Suppositions ['hypolépseis']" (D. Laertius. Lives of Eminent Philosophers, edited and translated by R. D. Hicks. Cambridge: Harvard UP, 2006, vol. 2, pp. 310-311, VII.197); as well as one

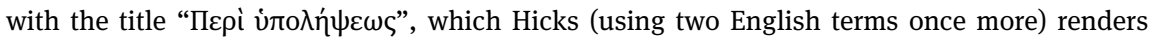


scholarly consensus appears to have been reached as to Aristotle's acceptations in particular. ${ }^{22}$ The term has been conceived of as being primarily of

"Of Opinion or Assumption” (pp. 316-317, VII.201); thereto, see also von Arnim (SVT II, p. 8, $\S 15$, and p. 9, § 17, respectively); the scholar adduces another intratextual occurrence of the term via a quotation in Plutarch (p. 291, § 994); similarly via Stobaeus (as 'hypolépseos', SVT III, p. 92, § 378), and Aspasius (as 'hypólepsin', p. 94, § 386); the latter’s citation is taken up in Seneca’s Latin as “opiniones” (SVT I, p. 81), “opinionibus” (p. 82, § 359; see Seneca, Epistles 93-124, p. 14, XCIV.6, and p. 18, XCIV.13); von Arnim also gives a long quote from Stobaeus, where Chrysippus uses the term three or four times (one may be an erratum, see SVT III, p. 147n.), in connection with various verbal forms (e.g. 'hypolambánein', pp. 146-147), and affine terms such as 'katálepsis' (here as 'akatalépto', 'katalépseos', and probably 'katálepsin'), spec. in a context concerning common knowledge (using the terms 'doxázein', 'dóxas', 'pístin', 'epistémen', 'epístasthaî', 'pisteúein', for instance; p. 147, §548; see p. 147n.); in a comparable context, Sextus quotes Chrysippus as using the term "író $\lambda \psi ı$ ”" (SVT III, p. 164, § 657; see Sextus, Against the Logicians, p. 230-231, I.432, where it is given as “conception”). For the later Stoic usage, see Marcus (Meditations, pp. 146, VI.30; p. 308, XI.18; p. 326, XII.7), also

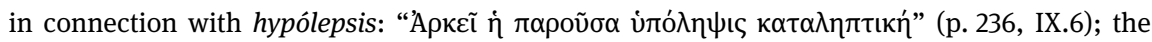
Stoicizing use is (re)applied to Heraclitus in a Christianizing appropriation by Clement of Alexandria and Hippolytus of Rome: 'katalépsetai' (see Vorsokratiker 1, p. 157, 22B28; p. 157n.; p. 165, 22B66; p. 165n.; Heraclitus. “On the Universe,” edited and translated by W. H. S. Jones. Hippocrates. Volume IV. Heracleitus. On the Universe. Cambridge: Harvard UP, 1931, pp. 469509, here pp. 478, XXVI, p. 478n.; p. 506, CXVIII, p. 506n.). In Epicurus' letter to Menoeceus, 'hypolépseis' are contrasted with 'prolépseis' - the former qua 'pseudeis', being of the 'pollon': "For the utterances of the multitude about the gods are not true preconceptions but false assumptions" (as given in: D. Laertius, Lives, vol. 2, pp. 650 f., X.124). For prólepsis (and several variants within a considerably dense space), see Epictetus (The Discourses. Books III-IV, edited and translated by W. A. Oldfather. Cambridge: Harvard UP, 1928, vol. 2, p. 256, IV.i.4144; generally, see Discourses I, edited and translated by Robert F. Dobbin. Oxford: Clarendon, 2011, pp. 42-44, I.22; p. 47, I.25.6; and his “Commentary,” pp. 188-193, 206).

22 In English, 'hypólepsis' (and the respective paradigm) tends to be rendered as (inter alia) 'supposition', 'suspicion', 'judgment', 'conception', 'assumption', 'opinion', or 'acceptation' (the latter's Latin form being how Aquinas translates it) - which is apt, but may not convey the dynamic tendency of the term ('take up', 'tie in with'). As to Aquinas, see Günther Bien ("Hypolepsis". Historisches Wörterbuch der Philosophie, edited by Joachim Ritter et al. Darmstadt: Wissenschaftliche Buchgesellschaft, 2013, Vol. 3., pp. 1252-1254, here pp. 1252 f.). Werner Theobald ("Spuren des Mythos in der Aristotelischen Theorie der Erkenntnis. 'Hypolepsis' bei Aristoteles, De anima und Anal. post.” Archiv für Begriffsgeschichte, vol. 44, 2002, pp. 25-37, here p. 37). On hypólepsis qua rhetorical "strategy" of "indirect statement", and for a nexus with the term hypónoia, see Kathy Eden ("Hermeneutics and the Ancient Rhetorical Tradition". Rhetorica: A Journal of the History of Rhetoric, vol. 5, no. 1, 1987, pp. 59-86, here pp. 74 f.); as to the latter, rendered "innuendo", see Aristotle (Nicomachean Ethics, edited and translated by H. Rackham. Cambridge: Harvard UP, 1934, pp. 246 f., 1128a, IV.viii.6); for the philosopher's use, compare also (Metaphysics, p. 4, 981a, I.i.5; pp. 8-11, 982a, I.ii.1-4; pp. 18 f., 983b, I.iii.4), given as "take the opinion which we hold" (Metaphysics, p. 9), "opinions which we hold" (Metaphysics, p. 11); with reference to the Thalesian 'natural' hypólepsis, as "derived this assumption”, "derived his assumption” (Metaphysics, p. 19) - i.e. directly from (the observation 
mythical import and implication by Theobald; this may seem questionable. ${ }^{23}$ Similarly problematic is Assmann's restrictive use: in his tripartite model, he

of) natural phenomena, implying a dynamic tendency. It is given as "suppositions", "supposition" ("Prior Analytics". Translated by Harold P. Cook. The Categories. On Interpretation. Prior Analytics, edited by Harold P. Cook and Hugh Tredennick. London: Heinemann, 1962, pp. 181531, here pp. 502-505, 67a-67b, II.xxi), and appears in the forms 'hypolambáno', 'hypolépsetai' (and further variants), translated as "think," "thinks," "thinking” ("Prior Analytics," pp. 504$507,67 \mathrm{~b}, \mathrm{II} . \mathrm{xxi})$. It is given as "judgement" - used in connection with, and as differentiated from, 'phantasía' (“On the Soul,” pp. 156-159, 427b, III.iii); as "belief” (p. 160, 428b, III.iii); and also offered as an overarching term: "Judgement ['tes hypolépseos'] itself, too, has various forms - knowledge, opinion, prudence, and their opposites, but their differences must be the subject of another discussion" (pp. $156 \mathrm{f}$., 427b, III.iii). The latter seems to refer to 1139b (see "On the Soul," p. 156n.), where it is given as "Conception" in connection with 'dóxe' qua both "capable of error" - the context being 'epagogè', "induction": "But all teaching starts from facts previously known” (Nicomachean Ethics, pp. 332 f., 1139b, VI.ii.1); and also as "belief,” "beliefs," "mode of conception" (pp. 339-341, 1140b, VI.v.6). The form 'hypoleptéon' is given as “deem”, 'apodektéon' (in the same sentence) as “accept” (pp. $626 \mathrm{f} ., 1179$ a, X.viii.12). It is translated as "conception" ("Topica”. Translated by E. S. Forster. Posterior Analytics. Topica, edited and translated by Hugh Tredennick and E. S. Forster. Cambridge: Harvard UP, 1960, pp. 263-739, here pp. 458-461, 125b-126a, IV.v), provisionally differentiated from pístis, here qua "belief” (pp. 458 f.); it is given as "opinion” (pp. 464 f.; see also: 300-301, 104b, I.xi.19 and I.xi.35), later as "conception” (pp. 628 f., 149a, VI.xi). It is also rendered "suspicion” (The 'Art' of Rhetoric, edited and translated by John Henry Freese. Cambridge: Harvard UP, 2006, pp. 436 f., 1416a, III.xiv.1), and "an inkling” (pp. 448 f., 1417b, III.xvi.10). There are other loci. Dionysius of Halicarnassus uses the term 'hypolépsetai' in a context concerning 'enárgeia' (sc. 'vivid description'; “Lysias”, Critical Essays. Volume I, edited and translated by Stephen Usher. Cambridge: Harvard UP, 1974, pp. 20-99), where the translation as "feel" may seem somewhat infelicitous: "Nobody who applies his mind ['diánoian'] to the speeches of Lysias will be so obtuse, insensitive or slow-witted ['bradỳs tòn noun'] that he will not feel ['ouch hypolépsetai', perhaps: 'will not be able to adopt, take (sc. the mental image, hence the perspective, before his inner eye, that of the mind), tie in with (the vivid description)'] that he can see ['horan'] the actions which are being described ['tà deloúmena'] going on ['ginómena']” (pp. 32-33, § 7). As far as is assessible, the haptico-emotional connotations of the English 'to feel' are not covered by the concept of hypólepsis; more significantly, the abovecited sentence explicitly stresses the intellectual plane (see the terms diánoia, nous, the latter ex negativo in its context); the immediately preceding sentence had emphasized Lysias' "grasp ['lépseos'] of circumstantial detail” (pp. 32-33, § 7) - whereby the scholar’s use of 'hypolépsetai' in his own description ties in performatively with the same paradigm at a grammatico-verbal level. Naturally, the (intended, ultimate) effect of this process will then be movere (wherefore "to feel" is indeed applicable de re); but Dionysius' textual economy seems to focus on the (decidedly controlled, or rational) method by way of which this is produced.

23 In academic terms, Theobald's speculative, quasi-metaphysical approach may seem a culde-sac. Its stress is selective (not to say reductive), ignores the initial (and arguably crucial) rhetorical meaning of the term - as also in (ps.)Plato, which Theobald denies (see "Spuren," p. 26); it does not take Ritter's and Marquard's adoption of this rhetorical use into account a brief reference to Bien's article remains without content-related consideration (see p. 25n.); it 
identifies the commenting mode of the "canon" and the imitative one of "classicism”, both defined by "repetition" (p. 282; trans. dsm; see pp. 102, 285 f.) as opposed to "referencing texts of the past in the form of a controlled variation", which 'critical' method he terms "“Hypolepse”" (p. 281; trans. dsm). ${ }^{24}$

also disregards Assmann's (re)application. Theobald's position is problematic in and of itself, particularly: "Und wie auch sonst, wenn nicht durch einen irgendwie als göttlich vorgestellten Eingriff" - including the ensuing speculations as to a Hegelian "Aufheben" being implied (p. 30). Theobald terms his approach "eine mythische Sichtweise" (p. 36), the implausibility of which he himself admits (p. 37). The tendency of Aristotle's overall œuvre is at variance with the Platonic approach, wherefore Theobald's vacillating attempt at drawing Aristotle closer to Plato (pp. 31-35) will not seem convincing de re. The decisive objection is posed by what Theobald treats to silence: hypólepsis is verifiably a rhapsodic, a rhetorical term (see Joachim Ritter. Metaphysik und Politik. Studien zu Aristoteles und Hegel, edited by Odo Marquard. Frankfurt: Suhrkamp, 2003, pp. 53, 64; Marquard, Skeptische Methode im Blick auf Kant. Freiburg: Alber, 1982, p. 76n.; Abschied vom Prinzipiellen, Stuttgart: Reclam, 2000, pp. 119, 139; Bien, "Hypolepsis,” pp. 1253 f.; Jan Assmann. Das kulturelle Gedächtnis. Schrift, Erinnerung und politische Identität in frühen Hochkulturen. Munich: Beck, 2013, pp. 282 f.); moreover, the term retains a link to common usage in Aristotle's applications of the concept - referring to 'phenomenistic' assumptions, views commonly held (then 'taken up'), to acceptations, customary 'wisdom', tying in with the communis opinio. The possibility of Theobald's later, mythical construal Ritter had already disproven (if the text be the measure) by reading Aristotle en détail: “Thales [...] knüpft das Göttliche als den 'Grund' an die Erscheinungen an; er begreift das vorher mythisch Vorgestellte jetzt - wie Aristoteles sagt - 'aus dem Sehen'. Das Sehen sieht das sinnfällig Sichtbare” (Ritter, Metaphysik, p. 54); "[e]ntscheidend ist also für Aristoteles die Anknüpfung der alten Vorstellung an das Sinnfällige; diese Anknüpfung wird im Begriff des Grundes zusammengefaßt” (p. 54n.); Ritter's reference is to Aristotle (Metaphysics, pp. 18 f., 983b, I.iii.4; see pp. 8-11, 982a, I.ii.1-4).

24 "Eine neue Form kultureller Kontinuität und Kohärenz entsteht: die Bezugnahme auf Texte der Vergangenheit in der Form einer kontrollierten Variation, die wir 'Hypolepse' nennen wollen. Dabei müssen wir sogleich eingestehen, daß das keinem quellensprachlichen Wortgebrauch entspricht" (Assmann, Gedächtnis, p. 281) - he does log the literal sense: "hypoleptische [...] 'Aufnahme' (nichts anderes heißt 'hypólepsis' ihrem Wortsinn nach)” (p. 283). “Hier handelt es sich um eine dritte Form des Rückbezugs, die man von Klassik und Kanon scharf unterscheiden muß, auch wenn sich Querverbindungen herstellen können” (p. 285); “[d]er hypoleptische Prozeß [...] Institutionalisierung von Autorität und Kritik” (p. 286). Assmann refrains from tying in with either Ritter or Marquard in this respect. His rather schematic application takes the term in a foreshortened sense, assuming that the 'taking up' must be institutionally "controlled" (p. 281; trans. dsm; see pp. 285-289) - his prime example being the relationship of "the Platonic Academy and the Aristotelian Peripatos" (p. 285; trans. dsm); that it must generally agree as to "criteria” concerning "the truth claim" (p. 287; trans. dsm; see p. 283); that the hypoleptic form of reference may not "alter the function" (p. 289; trans. dsm); in general, he emphasizes (textual) "fixation" (p. 283; trans. dsm), a "situative framework" (p. 284; trans. dsm; see p. 283), speaking of "the principle [']hypolepsis[']” (p. 286; trans. dsm). Assmann's idealistic or ideological restrictions would seem to bar virtually any pragmatic application of the term. In another context (referring to Blumenberg and Adorno), Haverkamp offers an arguably foreshortened 'genealogy' and problematic teleology of the term in ques- 
In contrast to Assmann's rather narrow, restrictive (and ideological) use, the essai at hand ties in with Ritter's reading of the term, as taken up and applied by Marquard, who describes hypólepsis as 'Anknüpfung' ('tying in with'). ${ }^{25}$ Aristotle uses the concept to signify that philosophy proceeds inductively, taking its initial assumptions and taxonomies from (linguistic) conventions and common ken - current, circulating, 'floating' in (virtual) cultural networks. ${ }^{26}$ It does not start from scratch (nor does it pretend to, like Des-

tion: “Die hermeneutische Tugend der 'Anknüpfung' und ihre spätere Vollendung zur Konsensfähigkeit, wie sie von Joachim Ritter erfunden, von Erich Rothacker befördert, von Hans-Georg Gadamer wirkungsgeschichtlich begründet und von Jürgen Habermas mit den höheren Weihen kritischer Theorie versehen wurde, steht noch in so unangefochtener Geltung, daß sie bis heute unhintergehbar erscheint" ("Das Skandalon der Metaphorologie. Prolegomena eines Kommentars”. Metaphorologie. Zur Praxis von Theorie, edited by Anselm Haverkamp and Dirk Mende. Frankfurt: Suhrkamp, 2009, pp. 33-61, here p. 33). By contrast, the essai at hand aims at tentatively charting a non-teleological - or rather, a 'poly-telic' - horizon (emphatic of what would potentially be a 360-degree view). Sommer's assessment of the philosopher's project is pivotal in this respect: "Nicht zuletzt öffnet die Art, wie Blumenberg die freie Variation handhabt, die Phänomenologie für grundsätzlich alles, was in anderen Wissenschaften gleich welcher Ausrichtung Thema ist. Phänomenologie, so betrieben, ist nicht exklusiv, sondern rezeptiv, zieht nicht Grenzen, sondern nimmt auf und eignet an" (“Nachwort”. Beschreibung des Menschen, pp. 897-906, here p. 902); "Wiederaufnahme von bereits Gesagtem ist [...] gelegentlich auch sachlich oder historisch vertiefte Neudurchdringung einer schon behandelten Thematik” (p. 906); arguably, (auto)hypólepsis with variation is a decisive Blumenbergian tool. Haverkamp does stress "Blumenbergs Tendenz zur Anknüpfung an Gegebenes" ("Nachwort. Die Technik der Rhetorik. Blumenbergs Projekt”. Ästhetische und metaphorologische Schriften, edited by Anselm Haverkamp. Frankfurt: Suhrkamp, 2001, pp. 433-454, here p. 441), and his remark on Blumenberg's modus in a concrete case may seem plausible, on the whole (that is, when provisionally quarantining the tendency added by the critic's context): "Blumenberg sortiert hier wie so oft einen Gemeinplatz [sc. 'Metapher'] um: der Anknüpfung wegen wie auch zum Zweck der Durchkreuzung, die auf dem Fuße folgt” (“Skandalon,” pp. 36 f.; employing the Derridean concept of "paleonymy'; see "Technik," p. 441, where Haverkamp stresses Blumenberg's "proclivity [...] for paleonymic formulations”; trans. dsm; compare Jacques Derrida. Dissemination, edited and translated by Barbara Johnson. Chicago: U of Chicago P, 1981, pp. 3, 6n., 18n., 21); "Durchkreuzung” may seem overstated, since it is apparently intended here in the sense of 'thwarting' (rather than 'intersecting' or 'traversing', which would arguably allude to retaining, in some form, what is thus decussated). The concept of 'subtending' (respectively 'subtension') might be more expedient.

25 Marquard’s (personal) hypólepsis: "von ihm [sc. Ritter] gelernt: [...] daß niemand von vorn anfangen kann, daß jeder anknüpfen muß” (Abschied, p. 7); "kein Mensch kann absolut von vorn anfangen, jeder muß - wie Joachim Ritter sagte: 'hypoleptisch' - an das anknüpfen, was schon da ist” (p. 78; see p. 90). Generally, see Blumenberg on the "Ökonomie des Nicht-mehranzufangen-brauchens" (Lebenszeit, p. 356).

26 See Aristotle: "no doubt it is proper to start from the known. [...] for us ['íñ̃v'] at all events it is proper to start from what is known to us ['apò ton hemin gnorimon']" (Nicomachean Ethics, pp. 12-13, 1095b, I.iv.5). Generally thereto, see Wesley Trimpi (Muses of One Mind. The Literary 
cartes or Husserl): “The load-bearing philosophical terms [...] are not posited by Aristotle. Philosophy takes them up 'hypoleptically' from preexisting linguistic usage" (Ritter, Metaphysik, p. 53; trans. dsm). ${ }^{27}$

Analysis of Experience and Its Continuity. Eugene: Wipf \& Stock, 2009), spec. "Aristotle maintains that we acquire knowledge by proceeding from what is more apprehensible to the senses [...]. We begin [...] inductively [...] these objects are more [...] intelligible to us (íñv)” (pp. 8788; see p. 122; as well as Trimpi's article "Reason and the Classical Premises of Literary Decorum.” Independent Journal of Philosophy, Vol. 5/6 (1988): pp. 103-111, here p. 108); "general

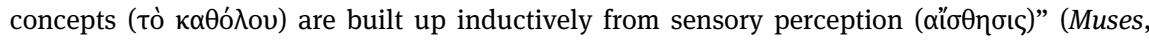
p. 92; compare pp. 47, 75-76, 119-123, 131-132, 232, 296-297, 331-332, 340, 367, passim). Accordingly, assumptions may also be derived from nature (respectively its observation) directly (as in Aristotle's example of the Thalesian 'natural' hypólepsis). Generally, see Kerferd: "What Aristotle does, almost regularly and as a matter of habit, is to take a current philosophical term or expression already in use, and then to refine it in such a way as to demonstrate that his own analyses and ideas were somehow already imperfectly present in earlier ideas already in currency" (The Sophistic Movement, Cambridge: Cambridge UP, 1999, p. 60). At times, Aristotle seems to limit the 'uptake' to the opinions of the wise (the latter valuation arguably being subject to variation, de re); inter alia, this is how Marcus uses it, particularly when quoting

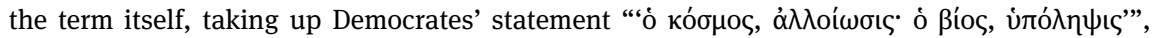
“"The Universe - mutation : Life - opinion”; he places it in a Stoicizing context: "disturbances are but the outcome of that opinion ['ن் $\pi \circ \lambda \eta \dot{\psi} \psi \varepsilon \omega \varsigma$ ] which is within us" (Meditations, pp. $70 \mathrm{f}$. , IV.3; see pp. 70n.-71n.). Likewise, Marcus explicitly ties in with "Monimus the Cynic" (p. 39,

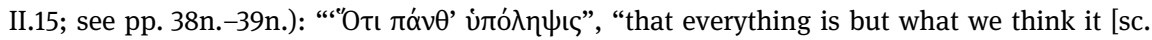
'what we take it to be']”' (pp. 38 f., II.15); see D. Laertius, stating that Monimus was "mentioned by the comic poet Menander [...] in [...] The Groom", where he is quoted as "pronouncing wholly vain / All man's supposings", 'tò gàr hypolephthèn typhon einai pan éphe' - said to surpass the 'gnothi sautón' (Lives II, pp. 84-87, VI.83). The dramatist takes up the Cynic, who is taken up by the Stoic; in this respect, see Marcus' remark as to what is herein termed (rhetorical) hypólepsis, and with respect to drama in particular: "and the dramatic writers contain some serviceable sayings" (Meditations, p. 297, XI.6); "[f]or that some serviceable things are said even by the writers of these [sc. New Comedies] is recognized by all” (pp. 297-299, XI.6); such hypólepsis from drama is similarly defended in Augustine: "hinc et ille comicus [sc. Terence, here], sicut luculentis ingeniis non defit resplendentia ueritatis" ("[Epistula] CLV”. S. Aureli Augustini Operum Sectio II Pars III: Ep. CXXIV-CLXXXIV, edited by Alois Goldbacher. Corpus Scriptorum Ecclesiasticorum Latinorum, Vol. 44. Vienna: Tempsky, 1904, pp. 430-447, here p. 444; see Political Writings, edited by E. M. Atkins and R. J. Dodaro. Cambridge: Cambridge UP, 2007, p. 97). The hypólepsis from Democrates (see also Vorsokratiker 2, p. 165, $68 \mathrm{~B} 115^{\star} 85$; as to the Pythagorean use, see Vorsokratiker 1, p. 473, 58D8), respectively Monimus,

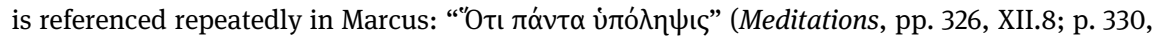
XII.22) - with this context: "that all is but as thy opinion of it, and that is in thy power. Efface

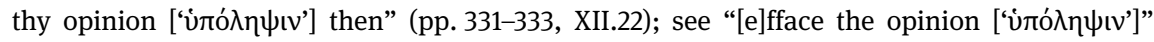

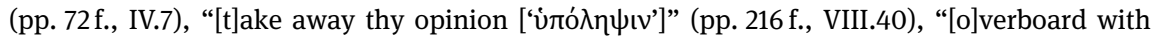
opinion ['ن́ró $\lambda \eta \psi \iota v$ '] and thou art safe ashore” (pp. 334 f., XII.25). Its meaning is not always

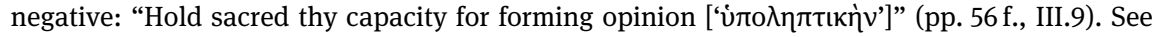

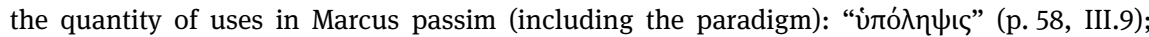




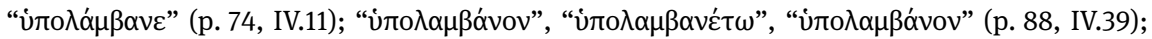

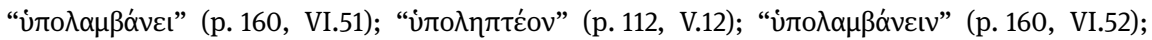

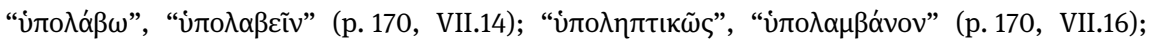
“ن்ло

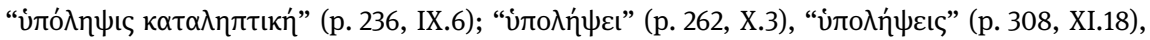

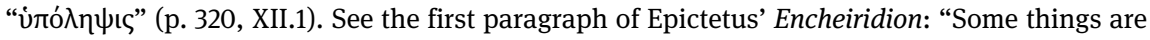
under our control, while others are not under our control. Under our control are conception

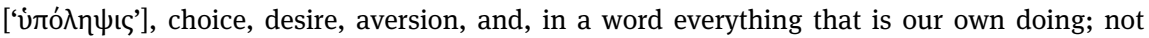
under our control are our body, our property, reputation [' $\delta$ 'ó $\alpha$ '] , office, and, in a word, everything that is not our own doing" ("The Encheiridion", edited and translated by W. A. Oldfather. The Discourses. Books 3-4. Cambridge: Harvard UP, 1928, pp. 479-537, here pp. 482 f., § 1). Via the two contrastive sets of enumerations, 'hypólepsis' is thus expressly contrasted with 'dóxai' (p. 482). The Stoa observes the difference in tendency: something that originates with another (the opinions of others) vs. what originates with or within oneself (one's own conceptions, assumptions). Naturally, the latter may also be (and usually, or often, is) an opinion seized from a common knowledge in circulation (general or particularized). As an offshoot of Platonic Socratism or Socratic Platonism, the Stoa may believe that it is possible to be taking one's conceptions from a realm removed from that of men and opinions. This is immaterial, here. As Karl Alfred Blüher notes (Seneca in Spanien. Untersuchungen zur Geschichte der SenecaRezeption in Spanien vom 13. bis 17. Jahrhundert. München: Francke, 1969), the aforequoted

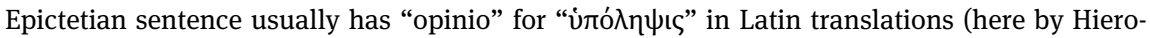
nymus Wolf), while Sánchez de las Brozas, possibly influenced by Juan Luis Vives, gives it as "la opinion y juicio de las cosas" in Spanish - a formulation taken up by Quevedo verbatim (Seneca in Spanien, pp. 286-287, 287n.).

27 Ritter continues: "Die Zusammenhänge, mit denen Philosophie zu tun hat, sind schon in der Art und Weise ausgelegt, wie von ihnen vorphilosophisch die Rede ist” (Metaphysik, p. 53).

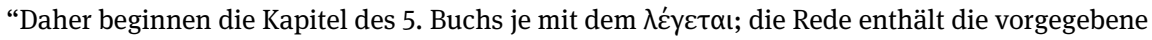
Auslegung” (p.53n.). "Diese vorgegebene Auslegung wird für die wichtigsten Begriffe im 5. Buch durchgenommen und entwickelt, um so ihren philosophischen Sinn in der Anknüpfung an sie zu umreißen. So wird auch der philosophische Begriff ápxń hypoleptisch begründet. Mit 'Grund' hat der Mensch immer schon - erkennend und handelnd - zu tun” (p. 53). This general method is fundamentally inductive, hence at variance with the Platonic overall tendency at a basic (hence structurally decisive) level; see Ritter: "eine Philosophie, die sich im Verhältnis zu dem, was ist, jede Konstruktion und Deduktion aus reinen Begriffen versagt” (p. 63). In this respect, and to qualify the above parentheses thereto, see Blumenberg, quoting from and glossing Husserl (the latter cited in italics): "Es gibt einen Übergang aus der Gemeinsprache in die phänomenologische Sprache: Die benutzten Wörter mögen aus der allgemeinen Sprache stammen, vieldeutig, ihrem wechselnden Sinne nach vage sein, aber sie können mit deutlichen und einzigen Bedeutungen ausgestattet werden" ("Sprachsituation und immanente Poetik”. Immanente Ästhetik - Ästhetische Reflexion. Lyrik als Paradigma der Moderne, edited by Wolfgang Iser. München: Fink, 1966 [Poetik und Hermeneutik II], pp. 145-155, here p. 146). In this regard, and with respect to the transmission of literary theory, see Trimpi ("adoption of terms", "a borrowed vocabulary”, Muses, p. 5; compare also pp. 9, 244, 265n.). See Blumenberg for a similar structure of tapping into what a given community is already primed for (hence familiar with) at the nominal (sc. here: meta-)level: "der Begriff des Symbols - vorgeprägt durch den des Symptoms in der antiken Medizin" (Schiffbruch mit Zuschauer. Paradigmen einer Daseinsmetapher. Frankfurt: Suhrkamp, 1979, p. 90). In general, hypólepsis signifies that one 
In line therewith, the concept's connective dynamics is accentuated herein. ${ }^{28}$ Its tendency is that of 'taking up' something (where someone has left off), of 'tying in with' a common ground; in Ritter's words: "Anknüpfung an die üblichen Vorstellungen", "tying in with customary notions" (Metaphysik p. 58; trans. dsm). Assmann's definition of "Hypolepse” qua "controlled variation" (Gedächtnis, p. 281; trans. dsm) marks a restriction that virtually never applies: for a 'tying in with' need neither be explicit - it often is not; nor need it share the same 'criteria', 'truth claims', or 'principles' (as Assmann believes) - in fact, it usually does not. ${ }^{29}$

For (decidedly) heuristic purposes, the following will select and detail three conceivable forms of the concept at hand, while simultaneously demonstrating their reciprocities; for theatrical, oratorical, and anthropistic hypolépseis cannot be strictly separated: dramatic variants are typically rhetorical, though not necessarily (immediately) concerned with assumptions about what it means to be human.

\subsection{With a View to Form and Function: Rhetorical hypólepsis}

The term 'hypólepsis' itself has a history of repeated 'uptakes'; in the context at hand, it will be needful to detail particularly the concept's rhetorical and philosophical ' $v i t a$ '. ${ }^{30}$ Initially, it seems to have been used with reference to

has to start somewhere - meaning, with a common ground. In the final analysis, any such will do: taken formally, an 'everyone knows' (see Niccolò Machiavelli. Il Principe, edited by Giorgio Inglese. Turin: Einaudi, 1995, p. 115, XVIII) is itself a structuring device (compare Leo Strauss. Thoughts on Machiavelli. Chicago: U of Chicago P, 1978, pp. 101, 210, 313n., 314n., 320n.) - that is, regardless of whether or not something is in fact known (let alone 'understood').

28 In T. S. Eliot's The Waste Land, spec. the "The Fire Sermon" (edited by Michael North. New York: Norton, 2001), two lines may be illustrative in the present context: "I can connect / Nothing with nothing” (p. 15, III, verses $301 \mathrm{ff}$.) - a metapoetic irony, seeing that (in a type of kaleidoscopic neo-analogism) almost all this long poem seems to be performing is to tie virtually anything in with everything else. As to a rhetorical uptake of (folk)lore, see its reference to “[a] children's nursery rhyme” (p. 19n.), which 'everyone knows': "London Bridge is falling down falling down falling down” (p. 19, verse 426). Technically, Eliot's modernist poem is hypoleptic kat' exochén.

29 Pace Assmann (Gedächtnis, pp. 281-289), who speaks of "the principle [']hypolepsis[']" (p. 286; trans. dsm). See Marquard: “das ‘Antiprinzip Anknüpfung” (Glück, p. 67). Naturally, the receiving context differs from - or may be entirely at variance with - the (textual) environment of the respective source or emitting discourse. Generally, see Stierle: "Wiederholung ist prinzipiell vom Wiederholten unterschieden" ("Moralistik," p. 2).

30 As detailed above, Marcus takes up the term 'hypólepsis' itself from Democrates (Meditations, pp. 70 f., IV.3; see pp. 70n.-71n.), and Monimus (see pp. 38 f., II.15), while integrating it 
recitals of Homer - where one speaker follows after another, 'tying in with' him, 'taking up' where the other left off. ${ }^{31}$ As Aristotle's use demonstrates, hy-

into a receiving context of Stoicizing tendency. Given a different textual environment, a(ny) concept naturally assumes various functions (often at variance with the emitting context or discourse), taking on (diachronically) manifold additional nuances of meaning.

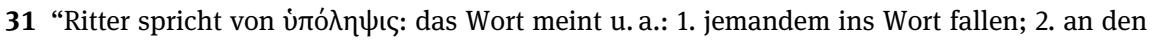
Vorredner anknüpfen; gemeint ist hier natürlich die zweite Bedeutung” (Marquard, Skeptische Methode, p. 76n.). See Assmann: "Das griechische Wort 'hypólepsis' wird in zwei typischen Kontexten verwendet, an die wir anknüpfen können. Der eine Kontext ist der Rhapsodenwettkampf. Hier bezeichnet man mit dem Wort 'hypólepsis' die Regel, daß der nächste Rhapsode genau dort in der Rezitation des Homertextes fortfahren muß, wo sein Vorgänger aufgehört hat. Der andere Kontext ist die Rhetorik. Hier bedeutet 'hypólepsis' die Anknüpfung an das, was der Vorredner gesagt hat. In beiden Fällen bezeichnet hypólepsis das Prinzip, nicht von vorn anzufangen, sondern sich in anknüpfender Aufnahme an Vorangeganges anzuschließen und in ein laufendes Kommunikationsgeschehen einzuschalten. Dieses Kommunikationsgeschehen bildet, was man den 'hypoleptischen Horizont' nennen könnte” (Gedächtnis, pp. $282 \mathrm{f}$.) - apart from the last sentence (which may seem to have idealistic implications), this synopsis of rhetorical hypólepsis is expedient. See the (ps.)Platonic dialog "Hipparchus," where

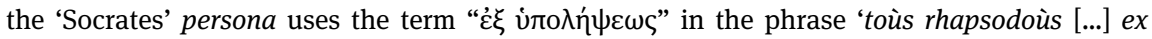
hypolépseos ephexes autà diiénai', translated as "the rhapsodes [...] recite them [sc. 'Homérou épe'] in relay, one man following on another" (in: Charmides. Alcibiades. Hipparchus. The Lovers. Theages. Minos. Epinomis, edited and translated by W. R. M. Lamb. Cambridge: Harvard UP, 2005, pp. 278-305, here pp. 288f., 228B) - a delegative process, incidentally. As Uwe Neumann shows de re (see "Agonistik." Historisches Wörterbuch der Rhetorik. Band 1: A-Bib, edited by Gert Ueding. Tübingen: Niemeyer, 1992, pp. 261-285), Homer's Iliad also features particular protagonists tying in with speeches made in earlier books (see p. 263), hence rhetorical hypolépseis that exceed an immediate verse-to-verse uptake: "Rede und Gegenrede wechseln auch im Wortkampf zwischen Thersites und Odysseus ab. [...] ein Vertreter des Volks ['mißt sich'] mit Odysseus. Thersites wird aber zugleich an Achilleus gemessen; denn er nimmt dessen Worte aus dem Streit mit Agamemnon genau auf (II, 240 = I, 356 u[nd] II, 242 = I, 232)” (p. 263). See Homer (Iliad. Books 1-12. Translated by A. T. Murray, and William F. Wyatt, edited by William F. Wyatt. Cambridge: Harvard UP, 2003, pp. 78-79, 2.240 and 241, with pp. 30-31, 1.232, as well as pp. 38-39, 1.356). In terms of versification, stichomythía has formal affinities to hypólepsis, while also conducing to the latter in terms of content and argumentative dynamics; for an Early Modern example in Gryphius, see Jörg Wesche ("Verse Games. Meter and Interactional German in the Baroque Plays of Andreas Gryphius", Rhetoric and Drama, edited by DS Mayfield. Berlin: de Gruyter, 2017, pp. 135-150, here p. 146; in the same volume, Jan Bloemendal, "Rhetoric and Early Modern Latin Drama. The Two Tragedies by the 'Polish Pindar' Simon Simonides (1558-1629): Castus Ioseph and Pentesilea”, pp.115-134, here p. 118; as well as Eden, "From the Refutation of Drama to the Drama of Refutation," pp. 55-70, here p. 59; see also Mayfield, “Interplay,” pp. 16n., 20, 20n., 31, 34). A rhetorico-hypoleptic approach (qua 'taking up and tying in with') is particularly need- and feckful in all forms of contentious and controversial exchanges - that is, with a view to the opponent; Quintilian recommends drawing upon, and indirecting, the respective other's verbal force - "The most satisfactory thing is if you are in a position to derive an Argument from your opponent ['ex adversario ducere argumentum']" (Institutio Oratoria 6-8, edited and translated by Donald A. Russell. Cam- 
pólepsis is not limited to a specific relay, exchange, or altercation; it may also involve longer distances between the time when a notion enters cultural circulation (in a context or discourse of emittance), and when it is (randomly) taken up again from common knowledge. ${ }^{32}$ In a textual environment, hypólepsis may occur intra- and intertextually, hence trans-spatially, across languages, and naturally over time. Aristotle's descriptions of man have themselves become 'Anknüpfungspunkte' (sc. 'points wherewith to tie in') - for implicit, typically unsystematic, nonlinear, uncontrolled, even entropic variations. ${ }^{33}$

bridge: Harvard UP, 2001, pp. 18-19, 6.1.4) - while also expressly tying in with the wording of the opposing party himself (see "ut ipsi vocant”, "to use their own phrase”, Institutio Oratoria 3-5, pp. 143-145, 3.8.58). Generally thereto, see Mayfield ("Otherwise. Rhetorical Techniques of Contradiction (With Remarks on Quintilian, Augustine, Machiavelli, Shakespeare, Gracián).” Contradiction Studies: Mapping the Field. Proceedings of the international conference held at the University of Bremen, February 9-11, 2017, edited by Gisela Febel, Cordula Nolte, and Ingo H. Warnke. Wiesbaden: Springer, forthcoming). See also the first sentence of the Téchne rhetoriké,

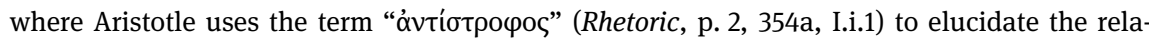
tionship between rhetoric and dialectic (see p. 3); this may be described as a form of hypólepsis, the term being familiar from choral music (p. 2n.). Philosophical discourse 'takes up' or 'ties in with' terms (and assumptions) in circulation, i.e. from the fund of common knowledge or other (established) discourses (sensu lato); see Küpper's discursive description of literature ("Was ist Literatur?" Zeitschrift für Ästhetik und Allgemeine Kunstwissenschaft, vol. 45, no. 2, 2001, pp. 187-215; here pp. 194, 205n., 214 f.).

32 Assmann does submit this notion: “'Dehnung des hypoleptischen Horizonts' [...], d. h. die Konstitution eines Beziehungsraums innerhalb dessen 'das, was der Vorredner gesagt hat', vor mehr als 2000 Jahren gesagt worden sein kann” (Gedächtnis, p. 283). He then rescinds the potential inherent in this insight by restricting the use of the term 'hypólepsis' in such a way as arguably renders it sterile (being idealized, overly schematic) in terms of scholarly serviceability.

33 For more methodical forms of hypólepsis - decidedly varying, altering, even subverting the tendency of the emitting statement, persona, or discourse - compare e.g. the assorted textual practices of sermocinatio, 'putting words in the mouth of' (thereto, see Heinrich Lausberg. Elemente der Literarischen Rhetorik. Ismaning: Hueber, 1990, pp. 142f., §§ 432-433; Handbuch der literarischen Rhetorik. Eine Grundlegung der Literaturwissenschaft. Stuttgart: Steiner, 2008, pp. 407-413, §§ 820-829; Strauss, Thoughts, pp. 42, 137-167; Mayfield, Artful Immorality, p. 91n.; “'Against the Dog only a dog'. Talking Canines Civilizing Cynicism in Cervantes' 'coloquio de los perros' (With Tentative Remarks on the Discourse and Method of Animal Studies)”. Humanities 6.2.28. Special Issue Animal Narratology, June: 2017, pp. 1-39, here pp. 12n., 18, 18n.-19n., 21, 21n., passim; "Variants of Rhetorical Ventriloquism in the Rhetorica ad Herennium, Cicero, Dionysius of Halicarnassus, Quintilian, and Augustine (with Remarks on sermocinatio, ethopoeia, and prosopopoeia)". History and Drama, edited by Joachim Küpper et al. Berlin: de Gruyter, 2019); as well as the method of 'accommodatio' (see 1Cor 9:19-27) and adaptation in rhetorical terms (see Kathy Eden. Hermeneutics and the Rhetorical Tradition. Chapters in the Ancient Legacy and Its Humanist Reception. New Haven: Yale UP, 1997, pp. 2, 14; Küpper, "Jesuitismus und Manierismus in Graciáns Oráculo manual”. Romanistisches Jahrbuch, vol. 58, 2007, pp. 412-442, here pp. 428 f., 429n.; Mayfield, Artful Immorality, pp. 218, 218n.; 
An oratorical angle on hypólepsis accentuates its form and function - the effectual application (also of anthropistic assertions) - in a specific (textual) environment (including dramatic works). It is grounded in the pervasiveness and prevalence of rhetoric as a multipurpose art, mediating between different cultural spheres (such as law, politics, etc.), and particularly until the Early Modern Age (also in the latter's drama). ${ }^{34}$ Oratory - qua versatile, trans-temporal téchne - plays an enabling role prior to considerations of individual agency or particularized institutions (to say nothing of supposedly 'national' specifics). ${ }^{35}$ The point of eloquence is ever (its) functionality, expediency: the "verità effettuale" (Machiavelli, Il Principe, p. 102, XV). ${ }^{36}$

Rhetorical hypólepsis is employed with a view to impact - as a feckful means for facilitating 'momentaneous evidence' in a given (and potentially any) addressee. ${ }^{37}$ The (relatively stable) structure of such utterances is linked

"Interplay," pp. 18-20, 18n.-20n.). In general, the rhetorical aptum (see also "Interplay,"
pp. 18, 18n., 21n., 31, 37) is highly hypoleptic at the metalevel - a rhetorico-cultural interleav-
ing that would require a separate study. For a nexus of sermocinatio and hypólepsis at the
historiographico-poetical level, see Neumann: "Historischen Persönlichkeiten werden fiktive
oder [...] überarbeitete Reden in den Mund gelegt; wobei die Argumente und der sprachliche
Ausdruck der Redegegner deutlich aufeinander bezogen sind" ("Agonistik," p. 264). In general,
the various forms of rhetorical hypólepsis 'take up (tie in with) and vary' foregoing instances
(oral, textual, or otherwise). As to the random modes, the vector may indeed be a downright
viral variation. 34 Generally thereto, see Bloemendal ("Rhetoric and Early Modern Latin Drama," pp. 115 f.); Küpper (“Rhetoric and the Cultural Net,” pp. 151-152, 156, 165); Mayfield (“Interplay,” pp. 5-8; see also "Talking Canines," pp. 12f.).

35 See Küpper's description of rhetoric as "a trans-generic system of diction” (Diskurs-Renovatio bei Lope de Vega und Calderón. Untersuchungen zum spanischen Barockdrama. Mit einer Skizze zur Evolution der Diskurse in Mittelalter, Renaissance und Manierismus. Tübingen: Narr, 1990, p. 300; trans. dsm; see also the English version: Discursive Renovatio in Lope de Vega and Calderón. Studies on Spanish Baroque Drama. With an Excursus on the Evolution of Discourse in the Middle Ages, the Renaissance, and Mannerism. Berlin: de Gruyter, 2017, p. 289).

36 The "effectual truth" (The Prince, edited and translated by Harvey C. Mansfield. Chicago: $\mathrm{U}$ of Chicago P, 1998, p. 61); 'one cannot argue with results' (says Calvin de re, hence the American idiom). For a structural similarity with a Thalesian hypólepsis (as described by Aristotle), see Machiavelli's apparently inductive approach: "mi è parso piú conveniente andare dreto alla verità effettuale della cosa che alla immaginazione di essa" - i.e. not to the 'dogmatic' (Platonic, Augustinian, etc.) utopias of "immaginati republiche e principati che non si sono mai visti né conosciuti in vero essere” (Il Principe, p. 102, XV; see p. 102n.; thereto, see Mayfield, Artful Immorality, pp. 182n.-183n.).

37 Jakobson's 'conative' function; for the latter's terms, utilized passim in the essai at hand (see Language, spec. pp. 66-71). As to "momentane Evidenz" (here mutatis mutandis), see Blumenberg (Arbeit am Mythos. Frankfurt: Suhrkamp, 2006, p. 533; Ein mögliches Selbstver- 
to their function, not least in that their form tends to effect an (apparent) recognition in the recipient (based on a perceived familiarity). While (latently) present, the content - reference(s), message, contexts, discourse(s) - is usually not immediately dominant: a rhetorico-persuasive purpose prevails. ${ }^{38}$ Such hypoleptic statements are often artful - terse, maximatic, acute, incisive (in this sense, Jakobson's 'poetic' function applies) - hence have a tendency to appear

ständnis. Aus dem Nachlaß. Stuttgart: Reclam, 1997, pp. 111, 122f., 124; Quellen, Ströme, Eisberge, edited by Ulrich von Bülow and Dorit Krusche. Berlin: Suhrkamp, 2012, p. 43; Theorie der Lebenswelt, edited by Manfred Sommer. Berlin: Suhrkamp, 2010, p. 180; Lebenszeit, pp. 114, 127, 137, 139; Beschreibung, p. 161).

38 Hence the concept and study of 'anthropistics' (as suggested herein), a portmanteau of 'ánthropos' and 'pístis' (implying both 'persuaded of' and 'persuaded by'); as to the latter, see Lausberg (Elemente, p. 15, § 6; p. 33, §65; Handbuch, p. 140, § 257; p. 190, §§ 348-349). In the exordium to Gorgias' "Encomium of Helen," "ríotıs" is rendered "belief" in the translation (The Texts of Early Greek Philosophy. The Complete Fragments and Selected Testimonies of the Major Presocratics, edited and translated by Daniel W. Graham. Vol. 2. Cambridge: Cambridge UP, 2010, pp. 754-763; here pp. 754 f., § 49.2); the context implies an 'opinion' (here qualified as "united and unanimous") or 'conviction' (an assumption, of which people had been persuaded previously, say by the poets): "the belief of those who heed the poets and the report of her name" (i.e. not a belief in the gods, here) - precisely since Gorgias is attempting "to refute [...] those blaming Helen, [...] to put an end to the blame [...] to put an end to their folly"; and this "by giving reasoning to my speech" - i.e. by being convincing, and persuading, if not the blamers and detractors, then those who matter, the people (p. 755, § 49.2). Later, in connection with hypólepsis (de re), the translation has: "to tell the knowers what they know produces credence ['pístin'], but does not bring delight ['térpsin']” (pp. 756 f., § 49.5). In the "Encomium”, the term for 'opinion' is 'dóxa': "concerning most things most people take opinion ['dóxan'] as their soul's ['psychei'] guide” (pp. 758 f., § 49.11; the translation as 'soul' is problematic). The respective section culminates in a conjunction of both terms here at issue, accentuating them by end focus: "That persuasion proceeding via speech impresses the soul at will, can be seen by studying [...] the verbal competitions of philosophers, in which quick thinking is displayed, showing how changeable is the belief in an opinion [' $\delta$ ' $\xi \eta \varsigma ~ \pi i ́ \sigma \tau v ']$ ' (pp. $758 \mathrm{f}$., § 49.13). See the density of variants in the immediate vicinity: 'peithò', 'dóxan antì dóxes', 'ápista', 'dóxes', 'épeise’ (p. 758, § 49.13). Moreover, this entire segment (pp. $758 \mathrm{f}$., § 49.8-13) is saturated with variants of 'peithein' (including 'pistis') and 'dóxa', concluding with both side by side in a sort of concise peroratio to this crucial part of the "Encomium". As to 'pístis', see Aristotle, in particular (“Topica,” pp. 292 f., 103b, I.viii; Politics, pp. 554 f., 1326a, VII.iv.5; Rhetoric, pp. 14 f., 1355b, I.ii.2; pp. 150 f., 1375a, I.xv.1), including a translation of "pístis' qua "sufficient grounds" ("Posterior Analytics," pp. 1-261, here pp. 180 f., 90b, II.iii), as well as the remark: "But opinion ['dóxe'] implies belief ['pístis'] (for one cannot hold opinions in which one does not believe); and no animal has belief, but many have imagination" ("On the Soul," pp. 158 f., 428a, III.iii) while 'dóxa' had been given as a (sub)form of 'hypólepsis' before (p. 156, 427b, III.iii; with

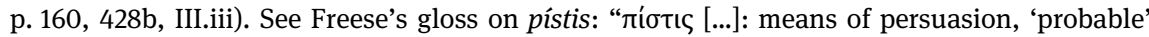
opposed to 'demonstrative' proof" (p. 479; compare Rhetoric, pp. 8-11, 1355a, I.i.11-12); see

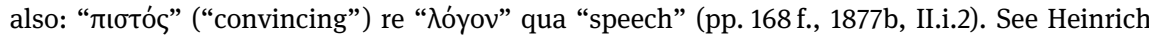




\author{
'momentaneously evident'. ${ }^{39}$ At times, they performatively emphasize their hy- \\ poleptic status itself. ${ }^{40}$
}

Niehues-Pröbsting: "True to its semantic origin, the term 'pistis' indicates [...] a work of the 'peitho”" (“Überredung zum Glauben”. Jahrbuch Rhetorik, vol. 34, no. 1, 2015, pp. 13-44, here p. 13); "Der Glaube (pistis) ist für den Griechen schon rein sprachlich ein Werk der Überredung” (p. 14); he offers an example from Clement of Alexandria: "Clemens [stellt] pistis und peithein so zusammen, dass dem griechisch geschulten Ohr die etymologische Verwandtschaft nicht entgehen kann" (pp. 28 f.). His general caveat is crucial: "was pistis in der griechischen Philosophie bedeute[t] [...] [ist] mit dem christlichen Glauben [...] unvergleichbar. Aufgrund seines Inhalts erfährt im Christentum der Glaube eine einzigartige Aufwertung” (p. 15); "Die Aufwertung manifestiert sich in der Singularisierung des Begriffs [...]. Die Rhetorik des Aristoteles untersucht die Mittel, viele verschiedene Meinungen und Überzeugungen zu bewirken; sie kennt nicht die eine ausschließliche pistis [...] die Pluralbildung in der Rhetorik" (p. 21). For the latter: "Weil es das [sc. 'logische Evidenz'] in der Rhetorik nicht gibt, sind hier mehrere Gründe notwendig und möglich; solche nennt Aristoteles pisteis. Das Wort bezeichnet [...] die Gründe, aus denen die Hörer dem Redner glauben (pisteuein)” (p. 16). Generally, a scholarly description will ask 'cui bono', inquire into the "utilitas causae" (Lausberg, Handbuch, p. 56, $\S 63$; p. 230, § 417) - it will perform an analysis of function; in Blumenberg's words: "Funktionale Interpretation verlangt demgemäß die Zuordnung der uns vorliegenden Aussagen zu den je akuten Problemen und zwar inhaltlich und formal" ("Epochenschwelle und Rezeption". Philosophische Rundschau, vol. 6, 1958, pp. 94-120, here p. 102); this, as well as the ensuing, applies to the essai at hand: "es geht um funktionale, nicht nur um topologische Verhältnisse" (Höhlenausgänge, p. 341n.).

39 See Lausberg as to terseness (Elemente, p. 135, §§ 407-409) and acuteness (p. 23, § 37; p. 61, 61n., § 166).

40 As Strauss stresses, "[t]he first word of the Prince is Sogliono ('It is customary')" (Thoughts, p. 23) - a performative instance of hypólepsis: an explicit tying in with what 'everyone knows' (or is said to know), while simultaneously accentuating or appealing to that very fact. Likewise in Machiavelli's “ciascuno lo intende” (Il Principe, p. 115, XVIII; see Strauss, Thoughts, pp. 101, 210, 313n., 314n., 320n.) qua 'everyone knows', 'it is (generally) understood': behind which lurks a "Io credo che tu creda" (Mandragola, edited by Guido Davico Bonino. Turin: Einaudi, 1980, p. 43, III.x) - thus Sostrata to her daughter Lucrezia (a parallelism, with polyptoton: repetition with variation). See also: "It is the verdict of ancient writers" (Discourses on Livy. Translated by Harvey C. Mansfield and Nathan Tarkov. Chicago: U of Chicago P, 1998, p. 78, I.37); "Everyone can understand" (p. 303, III.43); "Prudent men are accustomed to say" (p. 302, III.43). Incidentally, the second sentence of Blumenberg's Legitimacy of the Modern Age commences with a "Jedermann kennt" (Legitimität, p. 11; see p. 16) - the reference being the term 'secularization' (“'Verweltlichung”). He also indicates a rhetorically hypoleptic formula: "nicht erfunden, sondern vorgefunden” (Präfiguration. Arbeit am politischen Mythos, edited by Angus Nicholls and Felix Heidenreich. Berlin: Suhrkamp, 2014, p. 16); in the given context of prefiguration qua legitimization (concerning Alexander the Great), such 'rhetoric' need not be verbalized (albeit semioticized): "Kein Wort brauchte bei dieser Art der Rhetorik zu fallen [sc. inverting Xerxes' sacrifice]; sie war sinnfällig für jeden, der seinen Herodot und seinen Homer 


\subsection{Assumptions About Being Human: Anthropistic hypólepsis}

When anthropistic statements are employed, it is not necessary for them to be distinctive, or reasonably applicable only to humans (let alone to all) - nor even simply to be rational; they are used for effect, and do not constitute a (deductive, systematically consistent) type of «-logy»; consequently, anthropistic hypolépseis are rhetorical, first and foremost: a provisional plausibility is requisite, their persuasiveness prevails. ${ }^{41}$

In terms of metastructure, such assertions (tacitly) refer to a quaestio infini$t a$ and represent its respective answer (usually a tópos) - with the qualification that these specific loci are 'more common' than others; they (claim to) refer to

gelesen hatte"; "Es ist die höchste Form der Selbstlegitimierung, an den vertrautesten Primärakt der griechischen Geschichte und des griechischen Selbstbewußtseins Anschluß zu gewinnen” (p. 16); "Ein schon gebahnter Weg wird benutzt, und nichts schließt aus, daß er in umgekehrter Richtung begangen werden kann” (p. 17). For a general assessment in this respect, see Küpper: "Im politischen Diskurs hat das Schema, etwas Neues nicht als neu, sondern als bessere Neuauflage und Einlösung von etwas Altem zu präsentieren, vor allem legitimierende Funktion” (Diskurs-Renovatio, p. 462n.; Discursive Renovatio 461n.); anthropologically put: "Es hatte der Menschheit allezeit genügt, das Unbekannte als das längst Bekannte 'wiederzuerkennen'” (Blumenberg, Lebenszeit, p. 192). Generally, see Küpper, as to 'investing' something with “eine[r] elementare[n] Transparenz, im Sinn eines Anknüpfens an bereits 'Gewußtes' und insofern Legitimiertes” (Diskurs-Renovatio, p. 232; Discursive Renovatio 224) - de re, the appearance of such transparency is a sufficient, perchance the desired effect (man being the provisional being). (The notion of) 'legitimacy' is (always) hypoleptic; it need not tie in with 'the truth', only with what is (or will be) believed to be factual - the effectual being the persuasive: 'pistis' from 'peítho' (as employed herein).

41 Generally speaking, instances of this form of hypólepsis 'take up and vary' statements that 'contain, carry, and convey' anthropistic ken (the latter meaning: of and by what human beings - at a given time or during certain periods - are persuaded with respect to the question 'what is human'). As a provisional assessment: deductive 'anthropo-logy' posits (supposed) constants; inductive anthropistics focuses on and studies notions as to 'human invariants' factually in circulation (which are needful: man being mortal, limited, having to arrange himself with the state of his knowledge; see part 5 below). In general, rhetoric accommodates circumstances, variants - also in its very form: "variatio [...] varietas [...] als Gesamterscheinung der Rhetorik” (Lausberg, Handbuch, p. 142, § 257); thereto, see Mayfield, including on oratory's polyfunctionality in this respect ("Interplay," pp. 5, 5n.-6n., 8, 8n., 31). 
everyone. ${ }^{42}$ This gives them their 'conative' efficacy, their (often provocative) potential and (political) brisance. ${ }^{43}$

Implying the general question 'what is (a) human (being)', said utterances tender a particular(ized) answer. These are comparable in form and function: such maximatic sententiae tend to assert their taking up and tying in with common anthropistic knowledge; and to have a universal (kathólou) claim. ${ }^{44}$ Since

42 "Die loci communes [...] sind als solche Antworten auf (formulierte oder nicht formulierte) quaestiones [...] des judizialen [...] deliberativen [...] und epideiktischen [...] Bereichs" (Lausberg, Elemente, p. 130, § 393); a "locus communis (коเvò тóлоৎ)" is preceded by a "quaestio

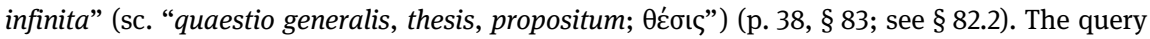
as to 'what a human being is' may be conceived as a quaestio infinita - both in the spec. rhetorical sense, and de re; as Lausberg indicates, such are often tacit or implicit (see Blumenberg's above remark as to 'meta-questions', Beschreibung, p. 502). 'Anthropistic' assertions are (or claim to be) 'phenomenistic', seeing that they state something (ostensively) general, universal - in the sense that potentially anyone might 'perceive' this (apparent) verity or state of affairs (concerning 'man's nature'). In the example Ritter selects from Aristotle, it is precisely not only common knowledge that philosophical discourse takes up (which a thinker may tie in with, or draw from), but also 'nature' itself (Metaphysik, p. 54, 54n.). This sense is present in Aristotle, who implies that Thales observed natural phenomena directly, 'tying in' therewith (see Metaphysics, pp. 18f., 983b, I.iii.4).

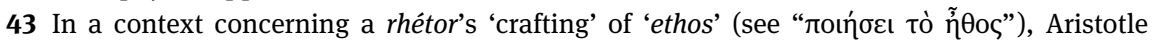
observes: "the hearers also are impressed in a certain way by a device employed ad nauseam

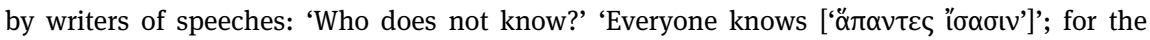
hearer agrees, because he is ashamed to appear not to share what is a matter of common knowledge" (Aristotle, Rhetoric, pp. 378-381, 1408a, III.vii.7).

44 "Ein in einem Satz [...] formulierter locus communis, der mit dem Anspruch auftritt, als anerkannte Norm der für die Lebensführung relevanten Weltkenntnis oder der Lebensführung

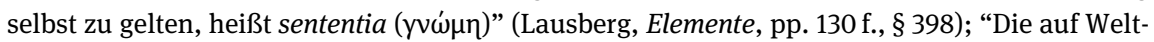
kenntnis bezüglichen Sentenzen [...] werden meist als Feststellungen [...] auftreten, während die auf die Lebensführung selbst bezüglichen Sentenzen [...] meist als Aufforderungen [...] formuliert sind. Die Grenzen in Inhalt und Formulierung sind fließend"; "Eine in besonders weitem Sinne infinite Sentenz wird (propositio) maxima genannt (fr. maxime, engl. maxim). - Eine in einer Sprachgemeinschaft als Volksweisheit verbreitete Sentenz wird 'Sprichwort' (proverbi-

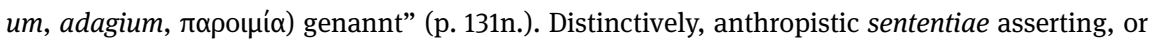
alluding to, human invariants display or imply a most universal claim; by necessity (given man's limitations in factual grasp vs. his at least potentially infinite notional reach), they have a tendency to be more frequently 'fabricated' (and then labeled as having been common ken and currency always already) than other maxims, in whose cases a (preceding) presence or prevalence may be verifiable to a certain extent; in other words: statements as to "what man is' are (supposed or assumed) to be plausible quasi- $a$ priori, since they (are taken to) tie in with what is accessible to anyone. Democritus' above remark is particularly pertinent, in baring said fact. Concerning the aspect of plausibility in rhetorical terms, see Gorgias: "cikòs", "probably" ("Encomium of Helen,” pp. 756 f., § 49.5); Aristotle accentuates the term "cikóৎ” (Rhetoric, p. 26, 1357a-b, I.ii.15; therein, see also Freese's "Select Glossary of Technical and Other Terms," p. 475), precisely in a passage that ties in with "Eikòs" in a poetic context via "tò 
the make or patterning of such remarks is relatively stable - hence memorable ('a human being is ...', 'all men are ...', 'man is the animal that ...', etc.) - they may be altered paradigmatically, but also 'fabricated' all but entirely, and still retain much of the weight and (rhetorical) color of previous anthropistic essais (of acknowledged, or once current, 'attempts at defining human beings'), specifically due to their form itself. ${ }^{45}$

Anthropistic statements are hypoleptic in a most general sense: attempts at defining man's 'tò tí en einai' take up and vary other floating essais (carrying and conveying notions as to 'human invariants') - explicitly, usually implicitly, and generally in 'free (uncontrolled) variation' (context and function will differ). Moreover, they might claim to be tying in with what is most accessible to all, what anyone may (allegedly) discern or experience for themselves: 'man is

kathólou', including a reference to " $\pi$ өөvóv" ("Poetics,” pp. 58-63, 1451a-b, § 9.1-18, 30-35). See Burckhardt: "das Geltendmachen des Plausiblen (Eikoৎ)” (Griechische Kulturgeschichte. Gesammelte Werke VII, vol. 3. Darmstadt: Wissenschaftliche Buchgesellschaft, 1962, p. 304); as to "probabile, credibile, verisimile”, 'pithanón', see Lausberg (Elemente, pp. 23f., §§ 34-38); compare Glenn W. Most ("Rhetorik und Hermeneutik: Zur Konstitution der Neuzeitlichkeit”. Antike und Abendland, vol. 30, no. 1, 1984, pp. 62-79, here p. 71).

45 In Poe's undulant formulation (from the ninth stanza of "The Raven"): "For we cannot help agreeing that no living human being” etc. (Selected Writings, edited by G. R. Thompson. New York: Norton, 2004, p. 59, verse 51) - the emphasis being on the immediacy of consent. As to 'color' qua rhetorical term, see Lausberg (Elemente, p. 36, § 73.1; 36n.). These maxims are 'momentaneously evident', 'eingängig' ('intuitive, memorable, captivating', implying 'common, customary', and including the dynamics inhering in the term 'current', from 'currere') like rhythms; as to the latter, compare Wesche ("Verse Games," p. 137). See Blumenberg, for a particularly notorious case in point: "Das Ich denke, ich bin war einer der erfolgreichsten philosophischen Sätze. Nicht nur wegen der Hinzufügung des 'also', sondern wegen der vielfachen Abwandelbarkeit des formalen Schemas, das mit diesem Satz vorgegeben war, in den sich je nach systematischer Gewichtung anderer Akte und Inhalte immer neue Wörter einsetzen ließen” (Lebensthemen. Aus dem Nachlaß. Stuttgart: Reclam, 1998, p. 130 f.). As regards memorability, two things seem needful and one conducive: first, such sententiae refer - particularly in terms of form - to a previous proverb, maxim, saying, aphorism that is common knowledge de facto, or said or thought to be; secondly, they are formulated in a rhetorically polished (usually terse) manner, and often employ repetition with variation (via alliteration, assonance, polyptoton, figura etymologica, paronomasia, etc.): that is, they are (auto-)cohesive and self-contained, hence transportable if fragmented or severed from their source context; thirdly, it is helpful if they are in some way measured (with many being metrically patterned indeed); theirs is an aural plausibility (also), which need not be conceptual. In this sense, Jakobson's 'poetic' function applies. In turn, said aspects conduce to hypólepsis. As a particularly notable instance, see Poe's parody of (Diogenes' mockery of) Plato's definition of man (Complete Stories and Poems. New York: Doubleday, n.a., p. 358; thereto, see Mayfield, Artful Immorality, pp. 25n.-26n.). 
what everyone knows' (as Democritus is said to have said). ${ }^{46}$ This implies that they transcend or subtend virtually any conceivable discursive limits, and are transposable in terms of linguistic setting, hence intersect and supersede (supposed) 'national' or cultural boundaries; in this sense, they have a 'cosmopolitan' claim: they (are said to) refer, pertain, or appeal to all humankind. If at all present, epistemological, or similarly 'logical' considerations (to say nothing of metaphysical ones) are secondary, here.

Essais concerning 'human invariants' may (or claim to) be tying in with former 'definitional attempts' as to 'what man is'; anthropistic hypólepsis marks a (more or less specific) allusion (also ex negativo) to common knowledge about human beings, which is - or used (or is said) to be - common currency, 'floating' in (virtual) cultural networks. ${ }^{47}$ Taking up a familiar form

46 On variants of sermocinatio (qua 'putting words into someone's mouth'), see Mayfield ("Variants of Rhetorical Ventriloquism" passim).

47 Machiavelli's œuvre is a particularly expedient example, in this respect. An explicit (albeit nonspecific, see Il Principe, p. 78n.) hypólepsis is used here: "It is the verdict of ancient writers that men are wont to worry in evil and to become bored with good, and that from both of these passions the same effects arise" (Discourses On Livy, p. 78, I.37); then follows an anthropistic appeal to a 'human invariant' ('man is the ambitious being'): "ambition [...] is so powerful in human breasts that it never abandons them at whatever rank they rise to. The cause is that nature has created men so that they are able to desire everything and are unable to attain everything" (Discourses on Livy, p. 78, I.37). Compare: "È cosa veramente molto naturale e ordinaria desiderare di acquistare" (Il Principe, p. 22, III) - the reference, context, or field of application ('man') being implied; an accentuation of human ambition is discernible in various discourses, also in Scripture, particularly in the Augustinian acceptation and emphasis with Machiavelli inverting the valuative tendency. See also: "Besides this, human appetites are insatiable, for since from nature they have the ability and the wish to desire all things and from fortune the ability to achieve few of them, there continually results from this a discontent in human minds and a disgust with the things they possess" (Discourses on Livy, p. 125, II.Preface); see Callimaco's soliloquy (addressing himself): "Don't you know how little good a man finds in the things he has desired, compared to what the man supposed he'd find there?" (Mandragola, edited and translated by Mera J. Flaumenhaft. Long Grove: Waveland P, 1981, p. 39, IV.i). In the Discorsi and Il Principe, the (tacit) quaestiones infinitae - 'what are human beings (generally speaking)' - and the respective answers are both universal: 'human beings are insatiable, driven by their appetites, ambitious'. In Mandragola, this generalized answer is implied, in turn. Like Aristotle, Machiavelli's works typically begin with, and are passim grounded upon, a certain conception of man (the 'acquisitive, self-interested, etc. animal'). The first preface (a privileged locus) commences with the adversatively assertive statement: "Although the envious nature of men" (Discourses on Livy, p. 5, I.Preface). Il Principe particularly focuses on 'man as a self-seeking animal': "Perché degli uomini si può dire questo, generalmente, che sieno ingrati, volubili, simulatori e dissimulatori, fuggitori de' pericoli, cupidi del guadagno" (Il Principe, p. 110, XVII; the last name of 'Callimaco' is “Guadagno”, Mandragola, p. 5, Prologo). Hence the reader is already primed for assessments such as "ogni occasione di propria utilità", stated in the vicinity of: "per essere gl'uomini tristi” (Il Principe, p. 111, XVII); 
for asserting what everyone knows - or is said or thought to know - with regard to man, these claims (answers to the quaestio infinita 'what is human') are hypoleptic in both form and function. ${ }^{48}$

Apart from (giving themselves the appearance of) being 'acceptations', anthropistic answers to the (tacit) quaestio 'what is a human being' tend to have a peculiar force or forte: they seem to immediately convey a sense of one's having been addressed (in 'conative' terms); such maxims (loci communes, tópoi, sententiae) are distinguished from other forms of common knowledge in that answers as to man's (peculiar) being have a general appeal (including such as may be per se appalling), being potentially directed at one and all. ${ }^{49}$ This is particularly the case in drama, where the expediency of appealing to everyone - to what is (taken to be) common knowledge - will be patent as

this is stressed with a quasi 'general rule' as to an implied 'man is the greedy animal': "perché li uomini sdimenticano piú presto la morte del padre che la perdita del patrimonio" (pp. $111 \mathrm{f}$., XVII); a counterexample occurs when the context demands that this 'general rule' be mitigated: "e gli uomini non sono mai sí disonesti che con tanto esemplo di ingratitudine e' ti opprimessino" (pp. $150 \mathrm{f}$., XXI). The self-interested nature of human beings is then repeated with formulations such as: "quando tu vedi el ministro pensare piú a sé che a te", "l'utile suo" (p. 155, XXII), “de’ consiglieri, ciascuno penserà alla proprietà sua” (p. 159, XXIII). It is arguably irrelevant whether or not the reader actually agrees, or wishes (or cares) to concur with such claims (let alone take delight in them); for it is assumed that 'everyone knows' this state of affairs (that 'it is understood'), wherefore such assertions tend to have 'momentaneous evidence' (also, and perhaps more effectually, malgré soi).

48 In this, anthropistic remarks are inevitably rhetorical, seeing that the arch-téchne works with, and insinuates (or engenders), 'familiarity' - a "Vertrautheitshorizont. Rhetorik arbeitet mit Vertrautheiten. Sie will nicht beweisen, sondern Widerspruch erschweren” (Blumenberg, Quellen, p. 212). Hence the recurrent formulation 'they say' is particularly applicable, here; see Ritter: “daß man [...] von dem ausgehen muß, 'was [...] gesagt wird”” (Metaphysik, p. 64); variants thereof are pervasive in La Celestina (edited by Dorothy S. Severin. Madrid: Cátedra, 2002), for instance - see (inter alia): "como dizen" (p. 107, I; compare p. 155, IV, p. 159, IV, p. 254, XI, p. 256, XII, p. 300, XV, p. 301, XVI, pp. 310-311, XVII), “dizen algunos” (p. 130, II; see p. 272, XII), “Pues dizen” (p. 137, II), “¿No has leýdo que dizen[?]” (p. 158, IV), “Por esto dizen” (p. 173, V), “bien dizen que” (p. 174, V), “No se dize embalde” (p. 256, XII), “No embalde dizen” (p. 265, XII), “No embalde se dize” (p. 307, XVII), “Todo el mundo lo sabe” (p. 342, XXI). 49 See Augustine's comment on the reception of the Terentian dictum (in part 4 herein). A maximal universality is their distinctive characteristic. Apart from being human oneself - and that everyone knows (and all have assumptions about) 'what man is' - virtually anyone will sense having been addressed, if a statement is of the form 'all human beings are'. The term 'rhetorical' signals 'purposiveness', expediency; here, the 'conative' is intricately interwoven with the 'poetic' function; the latter renders these remarks effortlessly transposable into other contexts; the 'referential', 'metalingual' functions (referring to the discourse, context, code) are typically not foregrounded; here and throughout, Jakobson's terms (see Language, pp. spec. 66-71) are used mutatis mutandis, as a heuristic device. 
regards the intra- and extratextual recipients (qua addressees of an anthropistic message). ${ }^{50}$

\subsection{With a Difference: Dramatic hypólepsis}

Due to its typically (including: virtually) dialogic form, rhetorical hypólepsis pertains to plays in particular (the anthropistic variant as the case may be). ${ }^{51}$ Certain oratorical devices are especially effective in dialog, hence in drama above all, distinctio..$^{52}$ Specifically theatrical and intratextual variants of hypólepsis may be encountered in comical exchanges - for instance in the form of dialogically productive (willful, accidental) misunderstandings, misnomers, or double entendre, where the 'metalingual' function is consequently express and

50 These or similar rhetorical appeals may bridge the 'horizon-related' gap between a text's time of production and the respective present (generally, see Hans-Georg Gadamer. Wahrheit und Methode. Grundzüge einer philosophischen Hermeneutik. Gesammelte Werke 1, Hermeneutik I. Tübingen: Mohr Siebeck, 2010, pp. 307-312, and passim; Hans Robert Jauß. "Literaturgeschichte als Provokation der Literaturwissenschaft". Rezeptionsästhetik, edited by Rainer Warning. Munich: Fink, 1994, pp. 126-162, here pp. 131-139). Apart from the always needful historico-philological considerations as to emitting and receiving horizon, 'reader response' would not be operational, if texts did not encompass a rhetorical potential to draw in virtually any recipient - simply on the basis that a text is written by humans, deals with things human, hence appeals to human beings (especially in terms of the Aristotelian 'kathólou', Poetics, pp. 58-61, 1451b, §9). Drama may be seen as a privileged locus for answering (and staging) the query 'what is man' in the particular.

51 See also the sample from Terence in section 4 (a rhetorical hypólepsis, with anthropistic tendency, in drama).

52 "Prov. [advancing] What's your will, father? / Duke. That, now you are come, you will be gone” (Shakespeare. Measure for Measure, edited by J. W. Lever. [Arden]. London: Thomson, 2004, p. 77, III.i.174-175; see Measure for Measure, edited by Mark Eccles. [Variorum]. New York: MLA, 1980, p. 149, TLN 1396-1397; the ensuing through line numbers refer to the latter edition); it may also have paronomastic color: "Ang. [...] Elbow is your name? Why dost thou not speak, Elbow? / Pom. He cannot, sir: he's out at elbow [sc. "without the wit to reply']" (p. 30, II.i.58-60; see 30n.; TLN 513-516); “[Esc.] What was done to Elbow's wife, once more? / Pom. Once, sir? There was nothing done to her once” (p. 34, II.i.138-140; TLN 591-593). In dialog, distinctio is a form of rhetorical hypólepsis. One might also be said to 'tie in with oneself', e.g. in a correctio, or in a repetition (for emphasis, insinuation); see "look in this gentleman's face [...] look upon his honour [...] Doth your honour mark his face” (p. 34, II.i.144-147; TLN 598-600); and Pompey's echoing his own line with slight variation: "Why, very well: I hope here be truths", "Why, very well then: I hope here be truths” (p. 33, II.i.126, 132; TLN 579, 585). See also Othello's "Put out the light, and then put out the light! / [...] But once put out thy light", including the murderous-luminous isotopy overall (Othello, edited by E. A. J. Honigmann. [Arden]. London: Thomson, 2001, p. 306, V.ii.7, 10; see verses 7-13). As to 'distinctio' - including 'antanáklasis' (“die dialogische [...] Realisierung der distinctio”), 'dubitatio', 
tends to be dominant. ${ }^{53}$ The following will stand in for countless possibilities in this respect:

Elbow. My wife, sir, whom I detest before heaven and your honour -

Esc. How? Thy wife?

Elbow. Ay, sir: whom I thank heaven is an honest woman -

Esc. Dost thou detest her therefore?

Elbow. I say, sir, I will detest myself also, as well as she [...].

(Shakespeare, Measure, p. 31, II.i.68-74; TLN 523-529) ${ }^{53}$

The phrase "My wife" is here taken up and grammatically altered according to the situation of communication; the constable repeats his own "heaven", while

'correctio' - see Lausberg (Elemente, pp.93-95, §§ 289-292, here: p. 95; see pp. 122-124, $\S \S 380-384$ ). In general, a rhetorical hypólepsis (perchance particularly in dramatic dialog) may also use the devices of figura etymologica and paronomasia to effect a repetition with variation; or a polyptoton, as here: "Esc. [...] It is but heading and hanging. / Pom. If you head and hang all that offend” etc. (Measure, p. 37, II.i.233-235; TLN 683-684); and (with paronomasia): "Esc. [...] Is it a lawful trade? / Pom. If the law would allow it, sir. / Esc. But the law will not allow it [...] it shall not be allowed" (p. 36, II.i.221-226; TLN 671-675). In another context (concerning verse), Stempel speaks of something being "in kontaktfördernder Position am Zeilenende" (in: Jauß et al., “Arbre,” p. 471); by and large, end focus tends to conduce to (rhetorical) hypólepsis; other such devices are anadiplosis, epi-, and anaphora, inter alia (generally thereto, see Lausberg, Elemente, pp. 82-83, § 250; pp. 86-89, §§ 265-273).

53 In this respect, see Jakobson's example of paradigmatic substitution in dominantly 'metalingual' dialogic contexts (Language, p. 69). The drama and its audience constitute a (virtual) pólis of sorts, naturally share 'currencies', establish commonalities, customary knowledge, conventions, for the duration of the particular play; this includes generic conventions concerning a kind of (explicit) contract between the actors and the audience (proposed, and usually entered into, in the exposition); see e.g. the prolog to Henry $V$, accentuating audience collaboration with regard to evidentia: "And let us [...] / On your imaginary forces work. / Suppose [...] / Piece out our imperfections with your thoughts. [...] / Think, when we talk of horses, that you see them [...] / For 'tis your thoughts that now must deck our kings [...] / Admit me Chorus [...] / Who prologue-like your humble patience pray" (Henry V, edited by T. W. Craik. [Arden]. London: Bloomsbury, 1995, pp. 120 f., Prologue 17-33). Generally, see Lausberg as to "captatio benevolentiae' with a view to 'delectatio' (Elemente, p. 35, § 69; compare p. 25, § 43; Handbuch, pp. 158 f., § 277); see also: “captan la benevolencia” (Baltasar Gracián. Oráculo manual y arte de prudencia, edited by Emilio Blanco. Madrid: Cátedra, 2011, p. 139, § 67), "la semejança concilia benevolencia” (p. 145, § 77).

54 See the entire scene (Measure, pp. 29-38, II.i.41-272; TLN 495-718). The glosses suggest: "he means 'protest"' (p. 31n.); see "Elbow. [...] I do lean upon justice, sir, and do bring in here before your good honour two notorious benefactors. / Ang. Benefactors? Well, what benefactors are they? Are they not malefactors? / Elbow. If it please your honour, I know not well what they are. But precise villains they are, that I am sure of, and void of all profanation in the world, that good Christians ought to have” (p. 30, II.i.48-56; TLN 503-511). The rhetorical hypolépseis here present are repetition with metalingual correction ("benefactors", "malefactors"), followed by a paradigmatic replacement ("villains"); a hypoleptic rearrangement and 
alluding to "honour" in "honest" (a figura etymologica); the "detest" is then given in antithetical terms ("thank heaven"), wherefore Escalus takes up "detest" with a view to effecting an auto-correction on the part of Elbow - who, echoing himself ("Ay, sir", "I say, sir"), does tie in therewith, but not in the manner likely to have been intended by the alderman..$^{55}$

In a serious context, Antony's oration - delivered after Brutus has spoken - is a specifically striking example as to how a particular 'tying in with' need not share the same assumptions (to say nothing of 'principles'), nor have exclusively textual implications. ${ }^{56}$ Brutus' reasoning after the slaughter stress-

reapplication of the same terms ("Well, what [...] are they", "I know not well what they are. But [...] they are"). As to Elbow, the glosses refer to 'transpositions', 'ironic misplacings' (p. 30n.; see 31n., 32n.); in the text itself: "Esc. [to Angelo] Do you hear how he misplaces?" (p. 31, II.i.87; TLN 542); an apparent misnomer particularly to the point in that context: "a woman cardinally [sc. 'carnally'] given” (p. 31, II.i.78f.; see 31n.; TLN 533-534; Elbow's misplaced term is capitalized in the Folio text - see Measure [Variorum], p. 64, with p. 64n.).

55 Generally speaking, correctio may be included as a variant in what one might term autohypólepsis. See a thematic 'tying in with oneself' in the Rhetorica ad Herennium: "quo facilius res cognosci possit, ne ab eadem sententia recedamus", "for the sake of greater clarity, to continue the same theme as above" (edited and translated by Harry Caplan. Cambridge: Harvard UP, 2004, pp. 366 f., IV.xliii.55); "ut ab eiusdem sententiae non recedamus exemplo”, “to continue the use of the same theme for my example" (p. 370 f., IV.xliv.56). Likewise, an instance taken from Shakespearean (script) variants might be termed a form of auto-hypólepsis (effecting a polyptoton): "Q 'laid' may be an actor’s echo from the previous line” - "I lay unto the grievous charge of others. / Clarence, whom I, indeed, have cast [or, as in Q, 'laid'] in darkness" (Richard III, edited by Anthony Hammond. [Arden]. London: Thomson, 2002, p. 169n.; re p. 169, I.iii.326-327). For a telling example of tying in with oneself (likely for reasons of legitimization), see Blumenberg: "Wahrscheinlich war es einer der fiktiven Antwortbriefe, die von ihm [sc. Descartes] in Umlauf gesetzt wurden, um auf gedachte oder indirekt übermittelte Einwände einzugehen" (Höhlenausgänge, p. 450). In this paradigmatic case, the intra-textual auto-hypólepsis is particularly patent: "21 March, night: Free. Soulfree and fancyfree. Let the dead bury the dead. Ay. And let the dead marry the dead" (James Joyce. A Portrait of the Artist as a Young Man, edited by John Paul Riquelme, Hans Walter Gabler and Walter Hettche. New York: Norton, 2007, p. 219, V.2630 f.); the glosses add: "Stephen cites and then transforms Luke 9:60" (p. 219n.).

56 Contrast Assmann (Gedächtnis, p. 283, with p. 281). If the environment is textual, the context cannot be identical, and the function will typically differ (at least in nuances), or be at variance entirely. For a historical example comparable to Antony's modus operandi in countering Brutus (as rendered in Shakespeare), see Quentin Skinner on Hobbes' technique: in Leviathan, the latter "picks up and deploys the distinctive vocabulary originally put into currency by the parliamentarian and radical writers of the 1640s" ("Hobbes on Persons, Authors and Representatives”. The Cambridge Companion to Hobbes's Leviathan, edited by Patricia Springborg. Cambridge: Cambridge UP, 2007, pp. 157-180, here p. 159); “crucial is the extensive use he makes in the revised version of his theory of the distinctive vocabulary developed by the parliamentarian propagandists of the 1640s [...]. What Hobbes is doing [...] is seeking to discredit these writers by demonstrating that it is possible to accept the basic structure of their 
es Caesar's 'plus ultra': “Ambition's debt is paid” (Caesar, p. 238, III.i.83); it is also at the center of Brutus' speech to the public: "but as he was ambitious, I slew him [...] and death, for his ambition" (Caesar, p. 254, III.ii.26-28). ${ }^{57}$

In a rhetorical hypólepsis, Antony's speech explicitly takes up this term and charge on the assassinator's part, while redirecting its force via a series of slight variations, ultimately leading to an utter 'refunctionalization' ${ }^{58}$ Employ-

theory without in the least endorsing any of the radical implications they had drawn from it. [...] this new rhetorical strategy in Leviathan" (p. 161; see p. 176n.); as per Skinner, the Early Modern theorist uses the same tactic against the "House of Commons", who had 'denounced absolute power' as “'a strange Monster to be permitted by mankinde”: "Hobbes unhesitatingly picks up and hurls back the taunt" (p. 175; see Skinner. "Hobbes on Representation". European Journal of Philosophy, vol. 13, no. 2, 2005, pp. 155-184, here p. 179) - i.e. by employing the term 'leviathan' emphatically.

57 This emphasis on Caesar's ambition refers back to Brutus' earlier deliberative soliloquy (see Julius Caesar, edited by David Daniell. [Arden]. London: Thomson, 2006, pp. 197-199, II.i.10-34), including an appeal to what is deemed the general knowledge in this respect: "But 'tis a common proof" - after which follows an explanation of the method of ambition and of such natures (p. 198, II.i.21; see II.i.22-27).

58 Jakobson speaks of "successive transformations" (Language, p. 90); the glosses have: "Part of Antony's skill in manipulation is in being gradual” (Shakespeare, Caesar, p. 257n.). See the respective speeches by Brutus (pp. 253f., III.ii.13-40) and Antony (pp. 257 f., III.ii.74-108); among other verses: "The noble Brutus / Hath told you Caesar was ambitious" (p. 258, III.ii.7879); "But Brutus says, he was ambitious" (p. 258, III.ii.87); "Did this in Caesar seem ambitious" (p. 258, III.ii.91); "Yet Brutus says, he was ambitious" (p. 258, III.ii.94); "Was this ambition? / Yet Brutus says, he was ambitious” (p. 258, III.ii.98-99). For a detailed analysis of Antony's speech, see Jakobson (Language, pp. 90 f.), especially: “Mark Antony lampoons Brutus' speech by changing the alleged reasons for Caesar's assassination into plain linguistic fictions. Brutus' accusation of Caesar, 'as he was ambitious, I slew him', undergoes successive transformations. First Antony reduces it to a mere quotation [...] The following polyptoton [...] presents the repeated allegation as mere reported speech [...] The most effective device of Antony's irony is the modus obliquus of Brutus' abstracts changed into a modus rectus to disclose that these reified attributes are nothing but linguistic fictions" (pp. 90 f.); Jakobson then demonstrates the way in which Antony takes up individual phrases and words on Brutus' part, redirecting them (see p. 91); and shows how the "dramatic force of Antony's exordium [...] is achieved by [...] playing on grammatical categories and constructions" (p. 90). One might also accentuate the performative 'tying in with' as such - meaning, rhetorical (intratextual, here quasidialogic), and then also anthropistic (trans-temporal, intertextual, trans-linguistic) hypolépseis. In the context of his theory of metaphor, Blumenberg notes the transformative dynamics of (implicitly) hypoleptic 'refunctionalizations': “[es] ist für Wirkung aufschlußreich, was nicht nur Wiederholung, Zitat, Referat, also unbedingte Anerkennung der Verbindlichkeit des Vorliegenden ist, sondern die Mühe des Umgangs erkennen läßt: Arbeit der Verformung über die Gedächtnisleistung hinaus, aber auch Anspielung, die immer das Verständnis des anderen voraussetzt, ohne es bestimmen zu wollen. [...] Wirkung ist eben nicht die Aufbewahrung von Figuren, sondern der vertraute oder auch sperrige Umgang mit ihnen” (Goethe zum Beispiel, edited by Manfred Sommer et al. Berlin: Suhrkamp, 2014, p. 44). Moreover, any 'tying in with' 
ing (inter alia) the rhetorical devices of parallelism, polyptoton, figura etymologica, antithesis, and irony, Antony's hypolépseis quasi-performatively keep

tends to be partial, poly-directional: "Was wir 'Hintergrundmetaphorik' genannt haben, der implizite Gebrauch einer Metapher, wird hier nochmals deutlich. Erst der Neuplatonismus hat diesen [Höhlen-]Mythos als 'absolute Metapher' genommen, teils anknüpfend an Empedokles und Plato, teils an die homerische Nymphengrotte, die in der Homer-Allegorese zu kosmischer Bedeutung aufgewachsen war, wie es des Porphyrios Traktat 'De antro nympharum' zeigt" (Paradigmen zu einer Metaphorologie. Frankfurt: Suhrkamp, 1998, p. 114). Such also yields formal or structural hypolépseis: "Am Höhlenmythos und mit dessen vorgeprägten Mitteln schafft Nietzsche die Rhetorik seines Antiplatonismus" (Höhlenausgänge, p. 627). As to Blumenberg's concept of "Umbesetzung" (sc. 'refunctionalization'), which reckons with (implicit, tacit) hypolépseis de re, see e.g. (Matthäuspassion. Frankfurt: Suhrkamp, 1991, p. 16; Lebenszeit, pp. 199, 203, 206; Höhlenausgänge, pp. 38, 296; Legitimität, pp. 52, 57 f.); particularly pertinent, here: "Der Gedanke der 'Umbesetzung' erklärt nicht, woher das neu eingesetzte Element stammt, nur welche Weihen es empfängt" (Legitimität, p. 60); "Die These von der funktionalen Umbesetzung als der Erzeugung des Scheins von substantieller Identität durch Säkularisierung ist eine Erklärung von Hartnäckigkeit, nicht deren Erleichterung oder Legitimierung” (p. 71; see pp. 75, 79, 89, 98 f., 157, 166 f., 257, 395, 399, 406); crucially (in that context, generally): "Es ist vor allem eine Ausdruckswelt, die sich durchhält. Die Sphäre der sakralen Sprache überlebt die der geweihten Sachen [...]. Die Umbesetzung von Systemfunktionen im Prozeß des Epochenwandels bedingt die sprachliche Konstanz in vielfältiger Weise" (pp. $87 \mathrm{f}$.; see also Begriffe, p. 17; "Wirkungspotential [2001]", pp. 380 f.; "Wirkungspotential [1983]", p. 49; Arbeit, p. 34; Beschreibung, p. 435; Sachen, p. 213; on the method of "Umbesetzungen", Höhlenausgänge, pp. 183-299; also on "Gegenbesetzungen”, pp. 301-411; spec. pp. 303f.); for applications of Blumenberg's concept, see Küpper (Diskurs-Renovatio, pp. 258, 274; Discursive Renovatio pp. 249, 265, 283; Mayfield, Artful Immorality, p. 170n.). For a particular case (as to Mach on Kant, infinitized here), see Blumenberg, noting “die formale Kontinuität der 'Umbesetzung' einer ihrer Funktion und theoretischen Leistung nach vorgegebenen Stelle im Text [...], obwohl der Autor gern von der Vorstellung des Bruches in seiner Entwicklung ausgehen möchte. [...] Umbesetzungen [...] sind nur vollziehbar oder nachweisbar, sofern Besetzungen stehenbleiben. Eine totale Umbesetzung ist ein Traum; wir würden nie erfahren, wenn sie vollzogen wäre” (Quellen, p. 160; see Lebenszeit, p. 51); the decisive statement in this respect (with the philosopher's reflections on his own concept): “Die 'Umbesetzungen', aus denen Geschichte besteht, werden rhetorisch vollzogen” (“Anthropologische Annäherung," p. 420), "Durchsetzung und Bestätigung der Umbesetzung sind rhetorische Akte” (p. 426). This ties in with his emphasizing “consensus als Ideal der Rhetorik" (p. 412); as a historical example: "Solche Rücksichten auf die Denkformen seines [sc. of Copernicus] Fachpublikums sind immer von der geringsten Schulspezifität - von Aristoteles oder Plato gerade so viel, wie zum Allgemeingut der Schulen geworden ist" (Die Genesis der kopernikanischen Welt. Die Zweideutigkeit des Himmels. Eröffnung der Möglichkeit eines Kopernikus. Frankfurt: Suhrkamp, 1996, 3 vols., vol. 2, p. 248; see p. 267). The latter marks a case in point for a decided functionalization of hypólepsis, and spec. with a view to (rhetorical) economy: "Die Komposition [...] ein Produkt der Assimilation", "eine höchst ökonomische Anpassung an die Rezeptionsbereitschaft der Zeitgenossen” (p. 297) here as regards the relationship of Copernicus' Revolutions to Ptolemy's Almagest. As to rhetoric: "weil Überredung Gemeinsamkeit eines Horizontes voraussetzt, [...] Anspielung auf Prototypisches, [...] Orientierung an der Metapher, am Gleichnis” (“Annäherung,” p. 412). Such 
the very fact of his 'tying in with' Brutus' speech alive in the minds of his audience, by continually reaccentuating this modus operandi in a series of warily varied, increasingly adversative repetitions; Antony's sequence ultimately leads to a paronomastically incisive anthropistic hypólepsis: “O judgement, thou art fled to brutish beasts / And men have lost their reason” (Caesar, p. 258, III.ii.105-106). ${ }^{59}$ The particularly "dramatic force” (Jakobson, Language, p. 90) of these terse and acute forms of hypólepsis heightens their 'momentaneous evidence' - both intratextually (with Antony's 'conative' appeal to the Romans including a form of stagecraft), and as regards the extratextual recipients. ${ }^{60}$

forms tie in with a given Lebenswelt, with what 'everyone knows' (or is said to know); they are universal (or give the impression of being so), hence portable (transferrable, translatable, as signaled by the term 'metaphérein'), dynamic; Blumenberg accentuates this tendency when speaking of "Arbeit an den Bildern" (Schiffbruch, n.pag.; intro. abstract, corresponds to p. 2). See Harald Weinrich's statement: "Bildfelder [...] gehören zum sprachlichen Weltbild eines Kulturkreises. [...] Es gibt eine Harmonie der Bildfelder zwischen den einzelnen abendländischen Sprachen. Das Abendland ist eine Bildfeldgemeinschaft" (Sprache in Texten. Stuttgart: Klett, 1976, p. 287). See Konersmann: "Europa, mit diesen Worten leitete Harald Weinrich vor Jahren die Rehabilitation des Rhetorischen [...] ein, sei eine 'Bildfeldgemeinschaft"” ("Vorwort: Figuratives Wissen.” Wörterbuch der philosophischen Metaphern, edited by Ralf Konersmann. Darmstadt: Wissenschaftliche Buchgesellschaft, 2014, pp. 7-20, here p. 11). Generally, Blumenberg notes: "Keine Erfahrung bewegt sich je in einem Raum völliger Unbestimmtheit" (Lesbarkeit, p. 16); the philosopher supposes an anthropogenic basis for the utilization (and 'endurance') of metaphors: “Lebensweltlich muss es immer schon Rückübertragungsverhältnisse der Anschauung gegeben haben, damit die Forcierung des Bewußtseins durch die Metapher ertragen werden konnte" (Schiffbruch, p. 79) - that is, a tying in with a basic structure or script pertaining to humankind, primed for various forms of Anknüpfung. With respect to a personal hypoleptic praxis, see Blumenberg's opening his contribution to the collaborative reading of Apollinaire's poem with the statement: "Ich möchte an die Äußerung von J. Taubes anknüpfen” (in: Jauß et al., “Arbre,” p. 481).

59 It is not just "perhaps" the case that "brutish" is "a pun on Brutus, dehumanizing" him (Caesar, p. 258n.); see Jakobson's assessment: “this apostrophe with its murderous paronomasia Brutus-brutish" (Language, p. 91).

60 The immediate reactions or effects are paramount; 'momentaneous evidence' is heightened in drama (especially if staged), since other factors will then conduce thereto, such as visual, auditory, 'emotive' stimuli, the overwhelming continuity, the drivenness of the plot; the latter in an Aristotelian sense: "tragedy is mimesis of an action [...] the plot is the mimesis of the action" ("Poetics," p. 49, 1449b-1450a, VI); "tragedy is mimesis not of persons but of action and life [...] and the goal ['télos'] is the most important thing of all” (pp. 50 f., 1450a, VI); "Plot [...] is the first principle and [...] soul of tragedy, while character is secondary” (pp. 53, 1450a, VI; see p. 57, 1451a, VIII). 
Instances of the anthropistic variant are frequent in drama. ${ }^{61}$ In addition to the innuendo in Antony's above statement, a reader or audience of Shakespeare might encounter other hypoleptic allusions to the Aristotelizing 'human invariant' of man qua 'animal rationale' - for instance in Hamlet's invective

61 Even so, it may not be expedient to refer to all humankind in all plots: some may require the staging of certain societal segments, at times gendered or profession-based, also for reasons of (sub)genre. Mandragola is built on the anthropistic assumption that 'all men are selfish'. The Prolog states an arguable verity about 'people in general' that might be translated into the definitional essai 'man is the finger-pointing animal' - here in a (self-interested) application by the speaker: "El premio che si spera è che ciascuno / si sta da canto e ghigna, / dicendo mal di ciò che vede o sente"; "che la gente, / vedendo ch'ognun biasma" (Mandragola, p. 6). Callimaco says about Ligurio: "I know that the likes of you live by cheating men" (p. 18, I.iii); the thesis might be: 'all parasites are fraudulent'. Naturally, the remark would be differently received in the form 'all human beings are leeches', or 'all men cheat'. When aiming to include the priest in the plot, Callimaco asks, Ligurio answers: "Chi disporrà el confessoro, tu? / Io, e denari, la cattività nostra, loro” (p. 30, II.vi) - i.e. 'everyone is greedy and wicked (perchance correlatively so)'. What receives a particularizing formulation here is generally articulated as 'all men are self-interested' in The Prince. In a soliloquy, the Frate gives the key to the play's conception of man indirectly: "Egli è vero che io ci sono suto giuntato; nondimeno, questo giunto è con mio utile” (pp. $42 \mathrm{f}$., III.ix) - the implicit praemissa maior: 'all men are eager for gain' (as Il Principe states expressly); the drama stages the universal sententia in (various) particulars. Later, Ligurio generalizes: "These frati are cunning, astute; and it stands to reason, because they know our sins and their own” (p. 29, III.2); 'all friars are sly' - a claim one of them later disavows: "Oh, how few brains are in these frati of mine!" (p. 49, V.i - says Timoteo). As a whole, and in all of its characters individually, this play stages the tacit quaestio 'what is man' with the (implicit) answer 'man is the (potentially consciously) self-interested animal' - express in the conduct of individual characters, and certain remarks on their part. The drama is not 'ahead of' theory or theoretical texts, as Paul Geyer believes (nor would such merit a 'value judgment'): “Literatur umschreibt immer das Selbstverständnis des Menschen. Als Wertkriterium für Hohe Literatur möchte ich ansehen, daß sie der zeitgenössischen Theorie vom Menschen voraus ist" "Intertextuelle Bezüge zwischen dem theoretischen und dem literarischen Diskurs: Machiavellis Il Principe und seine Komödie Mandragola”. Italienische Studien, vol. 18, 1997, pp. 91-102, here p. 91). Geyer's overstatement - "Eine Komödie ist dramatisierte Anthropologie” (p. 97) - contradicts his own thesis. Moreover, it is precisely not a «-logy that is staged (neither here, nor does such seem possible); likewise, as to his second claim: "Machiavellis Principe konstatiert den Zerfall des mittelalterlichen Menschenbildes. Seine Mandragola zieht daraus die Konsequenz und legt damit den Grundstein für eine neue Anthropologie" (p. 101). Geyer's conclusions are not only inconsistent with respect to his own thesis, and the factual function in drama; they are also problematic discursively: "Machiavellis Beschreibung der Natur des Menschen als grundsätzlich moralisch verderbt, womit er übrigens in große gedankliche Nähe zu Luther und Calvin rückt” etc. (p. 96). Discursively, a common recourse may be found in the Bishop of Hippo; but the respective functionalizations are at variance with each other, seeing that Machiavelli reads Augustine against the latter's grain: tendency matters - and function in a given context; see Blumenberg, as quoted above ("Epochenschwelle," p. 102). 
against his mother: "O God, a beast that wants discourse of reason / Would have mourn'd longer” (Hamlet, p.189, I.ii.150-151); as well as in his later speech:

What is a man / If his chief good and market of his time / Be but to sleep and feed? A beast, no more. / Sure he that made us with such large discourse [sc. 'power of reasoning'], / Looking before and after, gave us not / That capability and godlike reason / To fust [sc. 'become musty'] in us unus'd.

(Hamlet, p. 345, IV.iv.33-39; see p. 345n.) ${ }^{62}$

The pun is in the particular application: reason is to lead to (more or less) bestial behavior by the end of this soliloquy: "O, from this time forth / My thoughts be bloody or be nothing worth" (Hamlet, p. 346, IV.iv.65-66). Behind these remarks lies the (tacit) quaestio infinita 'what is man', with one answer being hypoleptically alluded to: 'man is the rational animal' - which (implicit) claim is either denied outright, or subverted (in terms of its function in context).

One Shakespearean passage featuring an anthropistic hypólepsis all but suggests itself for closer scrutiny. Towards the climax of a longer monolog in the presence of, or addressed to, Rosencrantz and Guildenstern, Hamlet leaps (or lapses) into an apparently learned - Humanistic, Stoicizing, Neo-Platonic, Mirandolian - mélange, hardly distinguishable in precise discursive terms (while it is also doubtful whether such would aid discerning its function in this specific context):

What piece of work is a man, / how noble in reason, how infinite in faculties, in form / and moving how express and admirable, in action / how like an angel, in apprehension how like a god: / the beauty of the world, the paragon of animals - / and yet, to me, what is this quintessence of dust? / Man delights not me[.]

(Hamlet, pp. 253 f., II.ii.303-309) ${ }^{63}$

62 Shakespeare (Hamlet, edited by Harold Jenkins. [Arden]. London: Thomson, 2003). In Aristotle, it is nature itself that does not perform anything sans reason, télos, or to no avail ('máten'): "For nature [...] does nothing without purpose” (Politics, pp. 10 f., 1253a, I.i.10).

63 The foregoing passage had already confirmed Hamlet's mind as prone to báthos (in the literal sense), when he first praises the magnificence of the skies or heavens - "this majestical roof fretted with golden fire" (Hamlet, p. 253, II.ii.301) - to then state that, in his "disposition" (p. 253, II.ii.298), "it appeareth nothing [...] but a foul and pestilent congregation of vapours" (p. 253, II.ii.302-303). The language is in stark contrast to the coarseness of the content, and this applies also to the following 'descent', which increases the intratextual 'drop height' from which that poly-discursive, abstract 'fall of man' occurs. The above punctuation has caused controversy; it may be problematic as to the terms "action" and "apprehension" (see Jenkins' comment in: Hamlet, pp. 468n.-470n.). 
Reasonably, this will not be received as an 'anthropological' consideration. Expressly, its function is 'emotive'. Obliquely (being directed at Rosencrantz and Guildenstern), it is 'conative', as the communicative situation bears out. ${ }^{64}$ The reference to a self-definition of man as "the beauty of the world" does have allusive potentials with regard to certain discourses, taking on some (or perhaps much) of their (rhetorical) color; inter alia, Stoicizing, Neo-Platonic discursive affinities are non-distinctively meshed together with partly Christianizing, Humanist speculations concerning human dignity. ${ }^{65}$ The particular application of this form, the function of this (mock-)appeal to man's grandeur, is the effect to be had - here by way of the anticlimax. ${ }^{66}$ The initial, global assertion - with the implied quaestio 'what is man' (Hamlet's interjection, a quasi-imperative that almost looks like the corresponding query), and various replies by way of anthropistic tópoi 'under variation' - serves precisely the particular rhetorical purpose at hand. To be construing this as Hamlet's (let alone an author's) 'anthropology' would not only seem anachronistic; for there is no (deductive) logic involved here, but an (inductive) rhetorical one - with

64 The rhetorical function is clear, both from the context and when taking this piece of verbal work in isolation.

65 Intratextually, as well as to the audience, they are unlikely to be distinct. See Jenkins' gloss concerning an earlier passage: "The idea of man as partaking of both god and beast which thus underlies the play is very much the Renaissance concept. [...] see Pico [...] De hominis dignitate" (Hamlet, p. 438n.; see pp.469n.-470n.); regarding Montaigne being "merely one example” for "a classical and Renaissance commonplace”, see Jenkins' remark (p. 468n.) here as to the description of the skies; while the superelevation of a particular author is problematic, the drift is pertinent: "Shakespeare is of course drawing on a common stock of ideas and terms [...] but the combination of them is quite his own" (p. 470n.). "As often Shakespeare achieves a magnificent result by combining elements, which, taken separately, are almost clichés” (p. 468n.) - that being precisely the point: their function is hypoleptic, seeing that 'everyone knows' (likewise as to most macrocosmic, or other discursive references, regarding astrology, humoral pathology, etc.). The 'conative' function - (self)persuasion (as implied in 'anthro-pistic') - is dominant (with a view to expediency). Any (supposed) 'agency' is subject to variation, rhetoric being an agent-indifferent, multipurpose téchne (see Küpper, DiskursRenovatio, p. 300; Discursive Renovatio, p. 289; "Rhetoric and the Cultural Net," passim; Mayfield, “Interplay,” pp. 5-8, 8n., 29n., 37-38, with further references). The 'referential' (discursive, intertextual) or 'metalingual' functions recede for the particular purpose in the specific drama, the corresponding act and scene, and the context into which they are embedded (also extra-dramatically, as regards the cultural framework of the recipients).

66 Couched in a statement to the effect that 'these are the private opinions held by the respective individual, and do not necessarily represent the state of either Denmark or the world' (ut ita dicam). 
a view to functionality and impact. ${ }^{67}$ The speaker is employing an anthropistic hypólepsis (distinctly dramatic in its textual environment).

On the whole, it must seem questionable to be positing an 'anthropology' based on suchlike assertions by characters embedded in plots and plays, in that the latter consist of multilateral contexts, differing causalities (whether apparently autotelic or ostensively manipulated), influencing what can at all, or will be said - as well as when, to whom and in whose presence, by which means, and to what end (that is, cui bono above all). ${ }^{68}$ It will hardly seem plausible to construe a systematic 'anthropology' on the part of a (supposed) author - let alone of the Early Modern Age generally - based on such or similar passages, and by abstracting from the particular purposes in a given context. The foremost function of anthropistic statements (such as appeals to 'human invariants') is hypoleptic; and especially when embedded in dramatic works, where a particularly dynamic constellation of (interested) causalities - of personae, nexus, utilitates - determines their function. Primarily, the latter will be purposive: directed at the intra- and extratextual recipients (respectively the speaker himself), and always with a view to (immediate) effectuality.

By means of its context, and regulated thereby, Hamlet's speech not only stages the question 'what is man' (formulated as a half-imperative, query-like, interjective thésis); it also tenders an enumerative cascade of sundry answers and not one. ${ }^{69}$ The 'referential', contextual, discursive, epistemic, 'metalingual' functions seem to be in the background: the dominant purpose is impact (the 'conative' function, here specifically by means of an anthropistic hypólepsis, functionalized with a view to a persuasively effectual anticlimax), inextricably interwoven with the form itself (the 'poetic' function, linked to the dramatic genre, here). ${ }^{70}$

67 It would also seem to strain the import of this passage in this particular drama from an extratextual viewpoint: for, like Polonius, the audience sees (and everyone knows by now) that 'there is method in this madness' (see Hamlet, p. 248, II.ii.205-206): much (rhetorical) practice, scholarly interest hardly - to say nothing of deductive 'anthropology'.

68 See Lausberg, citing a twelfth-century Latin hexameter: "quis, quid, ubi, quibus auxiliis, cur, quomodo, quando” (Elemente 25, § 41; see Handbuch 183, §§ 328; p. 203, § 374).

69 In anthropistics, one is dealing with 'quasi-definitional essais', not with 'definitions proper' (let alone 'sensu stricto').

70 See the Jakobsonian functions, mutatis mutandis (Language, spec. pp. 66-71). The emotive function of Hamlet's speech is connected to the conative one, seeing that it may seem to be auto-persuasive, as well (at least in part). 


\section{Nuances: 'Nothing Human Alien'}

homo sum; humani nil a me alienum puto.

Terence $^{71}$

At the outset of Terence's Self-Tormentor, the senex Chremes makes the above anthropistic statement. In Seneca, one encounters a rhetorical hypólepsis thereof: "Homo sum, humani nihil a me alienum puto". ${ }^{72}$ Taking a larger temporal leap, one will find a truncated version of the maxim in Nietzsche's Posthumous Fragments: "nihil humani - ist antik" (KSA 11, p. 444, §34.80, 'nihil humani pertains to Antiquity'). Moreover, one might come across Jakobson's paradigmatically altered version of the dictum (a transtemporal rhetorical hypólepsis, not immediately anthropistic): "Linguista sum; linguistici nihil a me alienum puto" (Language p. 93; see p. 510n.). ${ }^{73}$ Various other versions might be adduced. ${ }^{74}$

71 ("Heauton Timorumenos / The Self-Tormentor". The Woman of Andros. The Self-Tormentor. The Eunuch, edited and translated by John Barsby. Cambridge: Harvard UP, 2001, pp. 171-303, here p. 186, I.i.77).

72 "I am a man; and nothing in a man's lot / Do I deem foreign to me" (Seneca. Epistles 93124. Translated by Richard M. Gummere, Cambridge: Harvard UP, 2006, pp. 90 f., XCV.53). See Blumenberg for a reference to Voltaire on "Senecas [...] Homo sum, humani nil a me alienum puto" (Lebenszeit, p. 230, 230n.).

73 Thus Jakobson, précising his position at a conference of anthropologists and linguists in 1953; this claim also concludes the corresponding essay, "Linguistics and Poetics" (of 1958/ 1960); see the gloss: "Lévi-Strauss, C., R. Jakobson, C. F. Voegelin und T. A. Sebeok, Results of the Conference of Anthropologists and Linguists, Baltimore 1953” (Poetik, p. 121n.; see p. 119).

74 See Cicero, for instance, where the context is 'knowing one's duty', which may be obstructed by being "extremely self-centered": "est enim difficilis cura rerum alienarum. Quamquam Terentianus ille Chremes 'humani nihil a se alienum putat"' (On Duties [De Officiis], edited and translated by Walter Miller. Cambridge: Harvard UP, 1913, pp. 30 f., I.ix.29-30) - i.e. Cicero refunctionalizes (perchance, or rather likely, with a hint of irony) the decidedly self-interested quip on the part of Chremes (being inquisitive, intrusive, importunate) to show that otherthan-selfish conduct is possible. See another refunctionalization of Terence's dictum by Cicero, which takes it as a merely notional (idealistic, utopian) remark (thereby implicitly disclosing its rhetorical quality): "if the judgments of men were in agreement with Nature, so that, as the poet says, they considered 'nothing alien to them which concerns mankind' ['humani', ut ait poeta, 'nihil a se alienum putarent'], then Justice would be equally observed by all" ("De Legibus," edited and translated by Clinton Walker Keyes. De Re Publica [The Republic]. De Legibus [Laws]. Cambridge: Harvard UP, 2000, pp. 287-519, here pp. 332f., I.xii.33). Augustine takes up Menedemus' previous utterance also, thereby stressing the dialogic setting in the source (see “Epistle CLV,” p. 444; Political Writings, p. 97); his hypólepsis ("Homo sum, humani nihil a me alienum puto") is notable in expressly highlighting the situation of reception, particularly the audience's reaction: "cui sententiae fuerunt etiam theatra tota plena stultis indoctisque plausisse” ("Epistle CLV,” p. 445); this he uses for his specific purpose, decidedly refunctionalizing 
Above, the sententia appears in four different genera (drama, specifically comedy; epistolary writing; fragmentary, momentary notations; a scholarly paper). Jakobson's version no longer answers the universal quaestio ('what is it to be human'). Nietzsche's context does not mention Terence, but Homer, Aristophanes, Horace, Petronius, La Rochefoucauld: the point being that the latter's contemporaries (and the Germans of the speaker's present) are said to have no patience for this "nihil humani" - here functionalized as signifying a "Genuß an niederen Sphären" (KSA 11, p. 444, § 34.80). ${ }^{75}$

It will be patent that Seneca would not employ the sententia in said fashion. His context reflects on the "way to worship the gods", answering "to believe in the gods"; then follows the query of "how to deal with men", to which a Stoicizing speaker replies with the equivalent of the Greek 'katà phýsin': "Nature produces us related to one another, since she created us from the same source and to the same end"; the anthropistic Terentian verse follows, and is glossed as referring to a common humanity (Epistles 93-124, pp. 88-91, XCV.50-53). ${ }^{76}$ This is far from Nietzsche's reapplication; and similarity with Jakobson's transtemporal rhetorical hypólepsis is in form only.

In Terence, Chremes is talking to the drama's titular self-tormentor Menedemus; the former opens the play with a self-important speech, in which he finds fault with the latter for working so hard being so old - instead of (delegatively) putting others to work in his stead. Menedemus replies rather reasonably, effectively telling the meddler to be minding his own business: "Chreme,

the anthropistic maxim: "Indeed, the fellowship of all human spirits naturally touched the hearts of everyone, so much that everyone there thought of himself precisely as the neighbour of every other human being" (Political Writings, p. 97, CLV; see "Epistle CLV," p. 445). See Montaigne: "Humani a se nihil alienum putet" (Essais II, edited by Emmanuel Naya et al. Paris: Gallimard, 2009, p. 32, II.ii). See also Marquard's connecting a variant thereof - "Nichts Menschliches sollte dem Schriftsteller fremd sein" - with an exposition drawing on one of Aristotle's definitions of man (Skepsis in der Moderne. Philosophische Studien. Stuttgart: Reclam, 2007, p. 22).

75 Euphemistically put: 'to be taking pleasure in bodily functions'. "Derbheit und Deli katesse zusammen bei Petronius, auch bei Horaz: mir am angenehmsten. Es gehört zum griechischen Geschmack. Homer war den Menschen um La Rochefoucauld herum zu derb, sie konnten das Triviale nicht genießen. Sie hielten eine gewisse hohe Empfindung bei sich fest, wie jetzt viele Deutsche, und verachte «te`n sich, wenn etwas wie Genuß an niederen Sphären in ihnen sich regt〈e`. Aristophanes ist das Gegenstück: nihil humani - ist antik” (KSA 11, p. 444, § 34.80).

76 "Primus est deorum cultus deos credere" (Seneca. Epistles 93-124, pp. 88 f., XCV.50). "Ecce altera quaestio, quomodo hominibus sit utendum" (p. 90 f., XCV.51). "Natura nos cognatus edidit, cum ex isdem et in eadem gigneret" (pp. 90 f., XCV.52). "Homo sum, humani nihil a me alienum puto. / Habeamus in commune; nati sumus. Societas nostra” etc. (pp. 90 f., XCV.53). 
tantumne ab re tuast oti tibi / aliena ut cures ea quae nil ad te attinent?" ("SelfTormentor,” p. 186, I.i.75f.). ${ }^{77}$ In rejoining, the quick-witted interlocutor makes use of an intratextual rhetorical hypólepsis; taking up a word ("aliena”) and tying in with a phrase ("nil ad te") from Menedemus' response, Chremes turns them into said anthropistic sententia: "homo sum; humani nil a me alienum puto” (p. 186, I.i.76-77). The given context renders this remark a cunning defense of 'meddling with other people's business'. ${ }^{78}$ This is a long way from Nietzsche's and Seneca's anthropistic hypolépseis - while Jakobson's rhetorical uptake (with paradigmatic alteration) actually stays closest to the tendency in Terence. ${ }^{79}$

On account of their structural equivalence, the above Anknüpfungen still seem similar to their maximatic 'source type', which remains recognizable formally (some elisions and variations notwithstanding). Even so, the respective contexts tend to differ - some of which have little (or almost nothing) to do with each other; or are downright at variance with the emitting discourse (as well as among one another).

Anthropistic assertions imply the (arguably indelible) query: 'what is (it to be) human'. The corresponding replies (including non-answers, rhetorical refusals to respond) - given at a particular time, in a specific context, containing, carrying, and conveying knowledge as to 'human invariants', for instance - may be taken up and varied in new contexts. ${ }^{80}$ Hence the diversity of

77 Compare and contrast Menedemus' (gullible) exclamation: "ita comparatam esse hominum naturam omnium / aliena ut melius videant et diiudicent / quam sua!" ("Self-Tormentor," p. 230, III.ii.503-505).

78 Hence an idiomatic rendition is pertinent: "I'm human, and I regard no human business as other people's" (“Self-Tormentor," p. 187).

79 The paradigmatic replacement performed by Jakobson - which particularizes the otherwise general sententia (hence limits or reduces its scope) - demonstrates the extent to which a recipient will sense having been addressed (when compared to assertions of the form 'all humans are'): "Linguista sum; linguistici nihil a me alienum puto" (Language, p. 93; see p. 510n.); with this statement, Jakobson defends against claims stating that he be overstepping the limits of the specialist province of linguistics, that he be meddling with other people's claimed and declared business - that he be overly interdisciplinary.

80 Any '(re)uptake', (re)application, (re)placement - including what may appear as a 'mere' (or 'mimetic') repetition (thereto, see Borges' story "Pierre Menard, Author of the Quixote," Collected Fictions, edited and translated by Andrew Hurley. New York: Penguin, 1998, pp. 8895) - will result in variation, variance. Likewise, the hypólepsis itself may have engendered or necessitated this new context first of all. Compare and contrast the tendency in Nietzsche's ensuing declaration: "Zwei Aufgaben: das Neue gegen das Alte zu defendiren und das Alte an das Neue anzuknüpfen” (KSA 7, p. 714, § 29.212) - the directedness is crucial, here: 'the old' is retroactively (or retrospectively) tied in with, or adapted to, 'the new'. 
the (implicit) anthropistic answers above: in Terence, it is human to meddle; in Seneca, it is human to mingle; in Nietzsche, it is human to be corporeal. ${ }^{81}$

\section{Elementally Speaking: 'Zitierende Tiere'}

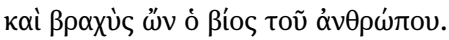

Protagoras $^{82}$

To distill the meta-theoretical yield of this essai so far: from a formal or structural perspective, hypolépseis tend to occur in grammatico-linguistic variants within immediate (dialogic, dramatic) exchanges, or intratextually associated contexts (including by the same speaker); in turn, transtemporal and intertextual uptakes typically have adaptive recourse to recognizable or familiar forms (such as the characteristic make of sententiae), refunctionalized with a view to (persuasive) effects in a receiving (often textual) environment; in terms of content, these Anknüpfungen may have a tendency to privilege broad-spectrum claims and appeals, for instance such as (are assumed to) pertain to all humankind. ${ }^{83}$ The efficacy of the latter may seem to be grounded in the fact that 'taking up and tying in with' is a vital modus operandi for this animal.

To provisionally conclude the present essai, a certain anthropistic 'invariant' will be briefly invoked by recourse to Shakespeare's King Lear, in order to elucidate said reciprocity between a hypoleptic héxis and humankind. During their retreat, Edgar is speaking to Gloucester, whose strength and will are failing: "Away, old man, give me thy hand, away! / King Lear hath lost, he and his daughter ta'en"; the father responds with a fatalistic maxim, "No further, sir; a man may rot even here"; to which the son answers with another sententia, "What, in ill thoughts again? Men must endure / their going hence even as their coming hither. / Ripeness is all. Come on" - "And that's true too" rejoins Gloucester, who does not ignore either the rhetoricality of the exchange

81 For Jakobson's rhetorical, not immediately anthropistic Anknüpfung, one might submit this implied essai, describing man (emerging kathólou, from the function of his hypoleptic variant in context): 'man is the curious animal capable of speech and self-reflection' (in Aristotelizing terms) - 'wherefore it may also (self-reflexively) inquire into its particular (linguistic) capacities'.

82 (In: Kranz, Vorsokratiker 2, p. 265, 80B4; and D. Laertius, Lives II, p. 464, IX.51).

83 With respect to the reasons for a hypoleptic refunctionalization, one might add that, "as in every rhetorical figure, the télos is variable: legitimizing, continuing, shifting, defacing, ridiculing, polemicizing openly, staging oneself" (with thanks to Prof. Küpper for this suggestion in a handwritten comment from Jan 5, 2016; trans. dsm). 
and its dicta, or the parity of their effective weight at the universal level (Lear, p. 363, V.ii.5-11). ${ }^{84}$

The various (implicitly anthropistic) hypolépseis here may be anything from a general 'man is a mortal being', to the Scriptural "There is a time for everything” (Ecc 3:1; NIV), Virgil's "stat sua cuique dies, breve et inreparabile tempus / omnibus est vitae” (“Aeneid VII-XII,” p. 204, X.467-468), or to Stoic equanimity (as the glosses suggest, see Lear, pp. 363n.-364n.) and "indifference as to death" (in Melvillean terms) - as well as myriad other maxims and discourses. ${ }^{85}$ The respective sententiae here deal with the conduct appertaining to, or effected by, this (anthropistic) knowledge: an (implicit) 'human invariant' - perchance, 'man is the being that potentially knows itself to be a dying animal' - serves as the hypoleptic 'anyone might know', 'it is understood'.86

As the Ancient Skeptics suggested (see Sextus, Outlines, p. 17, I.xi.23-24, for instance), it may be a viable (if temporary, tentative) solution to one's 'nes-

84 (King Lear, edited by R. A. Foakes. [Arden]. London: Bloomsbury, 2013). The above echoes "The readiness is all" (Hamlet, p. 407, V.ii.218). The last remark is given despite the direness of the circumstances: (perchance) a comic relief, depending on the recipient's perspective, respectively on the particular performance.

85 "Each has his day appointed; short and irretrievable is the span of life for all" (Virgil. "Aeneid VII-XII". Translated by H. R. Fairclough, and G. P. Goold. Aeneid VII-XII. Appendix Vergiliana, edited by G. P. Goold. Cambridge: Harvard UP, 2002, pp. 1-367, here p. 205); "there is a time for everything [...] a time to be born and a time to die" (Ecc 3:1-2); see Melville (MobyDick, edited by Hershel Parker and Harrison Hayford. New York: Norton, 2002, p. 266, ch. 75). 86 As to the "dying animal" ("It knows not what it is"), see the third stanza of Yeats' poem "Sailing to Byzantium" (Yeats's Poetry, Drama, And Prose, edited by James Pethica. New York:

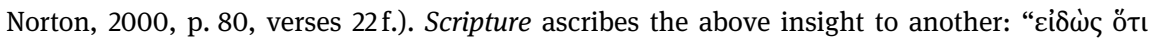

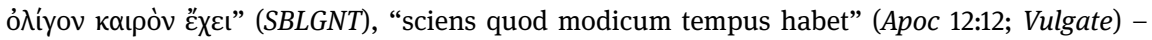
see Blumenberg (Schiffbruch, pp. 85 f.; Unbegrifflichkeit, pp. 104 f.; Lebenszeit, p. 71, 71n.), who adds: "diese[r] Satz [...] ist [...] kaum an die kulturellen Bedingungen seiner Herkunft gebunden; er ließe sich in jede beliebige Sprache mit einem anderen Namen übersetzen" (Schiffbruch, p. 86). Generally, see Montaigne's essai “Que Philosopher, c'est apprendre à mourir" (Essais I, edited by Emmanuel Naya et al. Paris: Gallimard, 2009, pp. 221-241, I.xx), which ties in with Cicero's “Tota [...] philosophorum vita [...] commentatio mortis est” (Tusculan Disputations, edited and translated by J. E. King. Cambridge: Harvard UP, 1945, p. 86, I.xxx.74), taking up “Plato, Phaedo 67 D” (p. 87n.). See Epictetus: "Will you not, as Plato says, study not merely to die" (Discourses III-IV, p. 303, IV.i.172) - with references to "Phaedo, 64 A, and Republic, II. 361 E” (p. 303n.). See Seneca: "Epicurus [...]: 'Think on death' ['Meditare mortem'] [...] it is a wonderful thing to learn thoroughly how to die. [...] 'Think on death'. In saying this, he bids us think on freedom. He who has learned to die has unlearned slavery [...]. His way out is clear" (Epistles 1-65, edited and translated by Richard M. Gummere. Cambridge: Harvard UP, 1917, pp. 190-193, XXVI.8-10). 
cio' to adopt - for the time being and the pragmatic affairs of life - the customs (the contingent nómoi, conventional mores, common usage) of a given time. ${ }^{87}$ The corresponding, inductive methods of observation and description are an infinite task, 'limitless labor'. ${ }^{88}$

It is an arguable 'human invariant' that said being must always exceed itself (and all that has been) - 'man is the animal plus ultra'. In the context at hand, this may translate into "theory, which simply cannot cease" theorizing (Blumenberg, Beschreibung, p. 498; trans. dsm). ${ }^{89}$ Yet it cannot always (nor

87 For the most part, this mode was adopted by Montaigne, one of the keenest Early Modern observers of humankind and its mœurs. See Heraclitus: "Therefore one must follow the com-

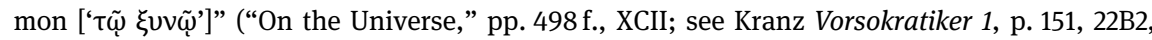
where Sextus' gloss reads: 'xynòs gàr ho koinós'; see the latter’s Against the Logicians, pp. 7273, I.133). Compare Blumenberg: "Die Menschheit hat den größten Teil ihrer Geschichte und des Volumens ihres Bewußtseins von unwiderlegbaren Annahmen gelebt und tut dies vielleicht - es ist ein Verdacht, des Beweises unfähig - immer noch” (Arbeit, p. 19). As to the function of assumptions in Blumenberg's thinking, see particularly: "Der Mensch ist ein Wesen der Ansichten mindestens ebenso, wie er eines der Einsichten sein oder werden mag. Wo er eine Welt hat oder sich gibt, hat er sich mit 'Weltansicht' begnügt und 'Welteinsicht' auch ohne Skepsis nicht in Aussicht. Erforschung der Metaphern hält inne im Vorfeld der Einsichten um den Ansichten ihr Recht widerfahren zu lassen” (Lesbarkeit n.pag.; foreword: "Über dieses Buch,” third p. thereof). In other words: familiarities, commonplaces, acceptations, assumptions - variants of hypólepsis. In a larger framework, this pertains to the Blumenbergian ethics of 'culture qua detour': "Kultur besteht in der Auffindung und Anlage, der Beschreibung und Empfehlung, der Aufwertung und Prämierung der Umwege. [...] Die Umwege sind es aber, die der Kultur die Funktion der Humanisierung des Lebens geben. Die vermeintliche 'Lebenskunst' der kürzesten Wege ist in der Konsequenz ihrer Ausschlüsse Barbarei. [...] Umwegskultur [...] diese[s] Barbareiverschonungssystem, genannt Kultur [...]. Die Unversöhnlichkeit des Pluralismus der Weltansichten ist ein Risiko, aber ein zureichend begründetes" (Die Sorge geht über den Fluß. Frankfurt: Suhrkamp, 1987, pp. 137 f.). Seneca's radicalism - "Remove existimationem hominum" (Epistles 1-65, pp. 188 f., XXVI.6) - would leave humans with nothing to go on; in this respect, Marcus' nuanced stance seems more viable, and considerably more humane (see the notes in part 3).

88 As Husserl put it and Blumenberg practiced it; see "Husserliana VIII 352": "Ich soll so leben, als ob ich unsterblich wäre und als ob ich wirklich ins Unendliche arbeiten könnte" (cited in: Beschreibung, p. 441; compare Blumenberg Genesis 2, p. 473; Höhlenausgänge, p. 715; Sachen, pp. 112, 146; Die Verführbarkeit des Philosophen, edited by Manfred Sommer. Frankfurt: Suhrkamp, 2005, p. 148; Schriften zur Technik, edited by Alexander Schmitz and Bernd Stiegler. Berlin:

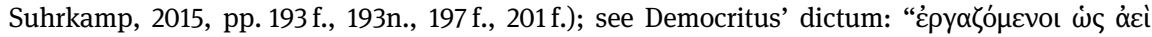

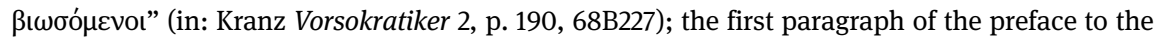
first book of Livy's Ab urbe condita: "Res est praeterea et inmensi operis" (History of Rome. Books 1-2, edited and translated by B. O. Foster. Cambridge: Harvard UP, 1988, p. 2); the resigned variant in Nicolaus of Oresme: “et labor interminabilis” (cited in: Blumenberg Legitimität, p. 409); the term "unendliche Arbeit" also appears in Nietzsche (KSA 11, p. 20, § 25.36).

89 See Marquard (in another context): "Theorie meint dabei in Anknüpfung an den ursprünglichen Wortsinn: Sehen und sagen, wie es ist. Theoriefähigkeit ist dementsprechend die Fähig- 
does it ever altogether) start from scratch (as Descartes and Husserl apparently tried) - 'life is short' and 'men limited'. ${ }^{90}$ Hence Marquard's describing 'man as the zoon hypoleptikón' (see Apologie, p. 68) - a 'hypoleptic animal' that 'takes up, ties in with, and varies' - is tentatively applicable, and perchance in the studia humanitatis above all: "human beings are beings that quote" ( $A b$ schied, p. 105; trans. dsm), 'man is a quotational animal' of necessity. ${ }^{91}$

Variants of (rhetorical, anthropistic, dramatic) hypólepsis were accentuated herein, particularly in terms of their artful form and function. Other empha-

keit, illusionsresistent zu sehen und zu sagen: So ist es” (Stattdessen, p. 135); “also der Sieg des So-ist-es über das So-hat-es-zu-sein” (p. 137). Given the plurality, diversity, contingency of the factual, this descriptive task is unlikely to be otherwise than endless.

90 As to Cartesian attempts: "Analog zu [...] Descartes [...] stilisiert Lichtenberg seinen Kopernikus, indem er ihm den Willen zuschreibt, den ganzen Plunder einmal wegzuwerfen und von neuem anzufangen. Fast wörtlich so hatte Descartes [...] sein Programm bestimmt: funditus omnia semel in vita evertenda" (Blumenberg, Genesis 2, p. 368); see other anti-hypoleptic examples: "die Nachwelt von der Überlieferung zu befreien" (Regiomontan, cited in: Lebenszeit, p. 128); in a context referring to Melanchthon: "das Bewußtsein von der Notwendigkeit, der Reformation ihre von Luther verachtete, aber nach der 'eschatologischen Phase' unvermeidbare Kulturfähigkeit zu geben und dafür den Schulrahmen der tradierten Bildung zu respektieren” (Blumenberg, Genesis 2, p. 387) prior, the philosopher had offered Melanchthon as an exemplar for a perceptively simulative hypólepsis: "In dem Kapitel mit der lapidaren Überschrift Quis est motus mundi? knüpft Melanchthon, so könnte man denken, an Luthers Neuerungsvorwurf an” (p. 378). As to human limits: "Der Mensch ist kein absolutes Wesen" (Marquard, Stattdessen, p. 7; see pp. 26, 45); Blumenberg: "Nicht die Trägheit macht die Tradition, sondern die Verlegenheit” (“Annäherung,” p. 427). Naturally, man is the being that refuses its limitations.

91 They are (actively) hypoleptic, (consciously) citational, (inevitably) referential beings: “denn die Menschen sind zitierende Lebewesen" (Marquard, Abschied, p. 105); "[d]enn die Menschen sind 'hypoleptische', sie sind anknüpfende Lebewesen" (Stattdessen, p. 42); "kein Mensch kann absolut von vorn anfangen, jeder muß - wie Joachim Ritter sagte: 'hypoleptisch' - an das anknüpfen, was schon da ist: Zukunft braucht Herkunft. Diese hermeneutische Einsicht” (Abschied, p. 78; see p. 90); “daß die Menschen nie von Anfang an anfangen. [...] Denn die Wirklichkeit ist [...] stets schon da, und sie müssen anknüpfen” (p. 76); “das Leben des Menschen [ist] stets zu kurz, um sich von dem, was er schon ist, in beliebigem Umfang durch Ändern zu lösen: er hat schlichtweg keine Zeit dazu. Darum muß er [...] 'anknüpfen'” (p. 16); “das Leben ist kurz, darum müssen wir [...] anknüpfen an Vorgegebenes” (Apologie des Zufälligen. Stuttgart: Reclam, 2008, p. 67); "Denn der Mensch ist - sterblichkeitsbedingt unvermeidlich - der wandlungsträge Anknüpfenmüsser, das Zoon hypoleptikon” (p. 68); “[j]ede Veränderung muß an Vorhandenes anknüpfen [...] hypoleptisch [...] das 'Antiprinzip Anknüpfung'. Anknüpfung - Hypolepsis - besagt: Das, was bleibt, ist die Möglichkeitsbedingung von Veränderung [...] Die Menschen können - wegen ihrer Sterblichkeit nie [...] in beliebigem Umfang von ihrem je besonderen Anknüpfungspunkt entfernt werden: Sonst zerstört man sie. Darum ist Ethik unvermeidlich Hypoleptik oder illusionär” (Glück, pp. 67 f.). 
ses and contextual embedments are conceivable and merit attention, given the time - as everyone knows: 'humana vita brevis'. ${ }^{92}$

92 Machiavelli's Mandragola commences with a Canzone, the first words of which are the tópos "Perché la vita è brieve" (p. 3); see the above quote from Protagoras (in: Kranz Vorsokra-

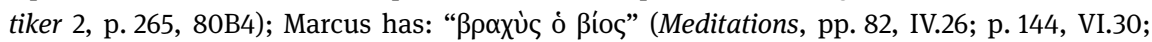

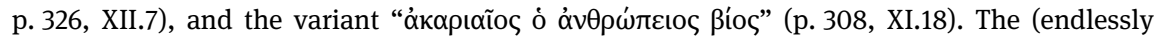
varied) 'source type' naturally being this Hippocratic aphorism: "Life is short, the Art long, opportunity ['kairòs'] fleeting, experiment ['peira'] treacherous, judgment ['krísis'] difficult” variants usually take up and alter only the first dicolon ('Ho bíos brachýs, he dè téchne makré'), and omit the medical context (98 f., I.i); see Seneca's "de brevitate vitae”: “"vitam brevem esse, longam artem”" (Moral Essays, edited and translated by John W. Basore. Cambridge: Harvard UP, 1932, vol. 2, p. 286, X; see p. 287n.). Referring to the Stoicorum Veterum Fragmenta, Pohlenz (Stoa und Stoiker. Die Gründer. Panaitios. Poseidonios, edited and translated by Max Pohlenz. Zurich: Artemis, 1950) tenders the following: "Zenon sagte, an nichts seien wir so arm wie an Zeit ['chrónou']. Denn wahr ist das Wort (des Hippokrates): 'Das Leben ist kurz und lang die Kunst ['brachỳs gàr óntos ho bíos, he dè téchne makré]', am meisten diejenige, die seelische Krankheiten ['tes psyches nósous'] zu heilen unternimmt” (p. 11; see p. 360n.; for the Greek, see von Arnim SVT I, p. 70, §323, who cites from Stobaeus); in the Modern Age, translating 'psyches' as "seelischen" is problematic - the point being ethical (hence this-worldly), not metaphysico-speculative. By and large, selectivity and truncation have a tendency of conducing to hypólepsis. For references, variants, see Blumenberg (Lebenszeit, p. 72); Goethe (Faust. Der Tragödie erster und zweiter Teil. Munich: dtv, 1962, p. 54, verses 1786 f.). 